\title{
Plug-In Hybrid Electric Vehicles: How Does One Determine Their Potential for Reducing U.S. Oil Dependence?
}

\author{
Anant Vyas*, Danilo Santini ${ }^{\circ}$, Michael Duoba*, Mark Alexander ${ }^{\dagger}$
}

\begin{abstract}
Estimation of the potential of plug-in hybrid electric vehicles' (PHEV's) ability to reduce U.S. gasoline use is difficult and complex. Although techniques have been proposed to estimate the vehicle kilometers of travel (VKT) that can be electrified, these methods may be inadequate and/or inappropriate for early market introduction circumstances. Factors that must be considered with respect to the PHEV itself include (1) kWh battery storage capability; (2) kWh/km depletion rate of the vehicle (3) liters/km use of gasoline (4) average daily kilometers driven (5) annual share of trips exceeding the battery depletion distance (6) driving cycle(s) (7) charger location [i.e. on-board or off-board] (8) charging rate. Each of these factors is actually a variable, and many interact. Off the vehicle, considerations include (a) primary overnight charging spot [garage, carport, parking garage or lot, on street], (b) availability of primary and secondary charging locations [i.e. dwellings, workplaces, stores, etc] (c) time of day electric rates (d) seasonal electric rates (e) types of streets and highways typically traversed during most probable trips depleting battery charge [i.e. city, suburban, rural and high vs. low density]; (f) cumulative trips per day from charger origin (g) top speeds and peak acceleration rates required to make usual trips. Taking into account PHEV design trade-off possibilities ( $\mathrm{kW}$ vs. $\mathrm{kWh}$ of battery, in particular), this paper attempts to extract useful information relating to these topics from the 2001 National Household Travel Survey (NHTS), and the 2005 American Housing Survey (AHS). Costs per kWh of PHEVs capable of charge depleting (CD) all-electric range (CDE, or AER) vs. those CD in "blended" mode (CDB) are examined. .Lifetime fuel savings of alternative PHEV operating/utilization strategies are compared to battery cost estimates.
\end{abstract}

Keywords: Plug-in Hybrid Electric Vehicle, Li-ion Battery, Energy Consumption, Vehicle Performance, Zero Emissions Vehicle (ZEV)

\section{INTRODUCTION}

The 2001 report by Graham et al discusses two methods of evaluating the potential for a plug-in hybrid (PHEV) to substitute electrically driven kilometers for kilometers fueled by gasoline [1]. The method that the Electric Power Research Institute PHEV working group preferred was the distance or mileage weighted probability (MWP) method. The MWP method assumes one full charge per day, with complete depletion of the battery each day. The MWP values, as well as an alternative utility factor (UF) values developed by the SAE J1711 subcommittee, were both developed from the same 1995 National Personal Transportation Survey (NPTS) data [2]. The 2001 EPRI report stated that "the SAE subcommittee also used NPTS to determine MWPs for all possible all-electric ranges from 0 to 500 miles at

* Center for Transportation Research, Argonne National Lab, 9700 S. Cass Avenue - Bldg 362, Argonne, Illinois 60439, U.S.A. Phone: +1 6302527578 Fax: +1 6302523443

${ }^{\circ}$ Center for Transportation Research, Argonne National Lab, 955 L’Enfant Plaza, SW, Suite 6000, Washington, DC, 20024, U.S.A.

Phone: +1 2024882431 Fax: +1 2024882413

$\dagger$ Electric Power Research Institute,

3420 Hillview Ave, Palo Alto, CA 94304-1395

Phone: +1 6508552489 Fax: +1 6508552737 one mile intervals. They then weighted these MWPs by all electric range, which resulted in Utility Factors (UF) ...that were less than the standard MWP." There is no quantitative indication in the EPRI report concerning how this was done. The authors of this paper are not aware of the foundational bases for the difference in MWP and UF values in Figure 1.

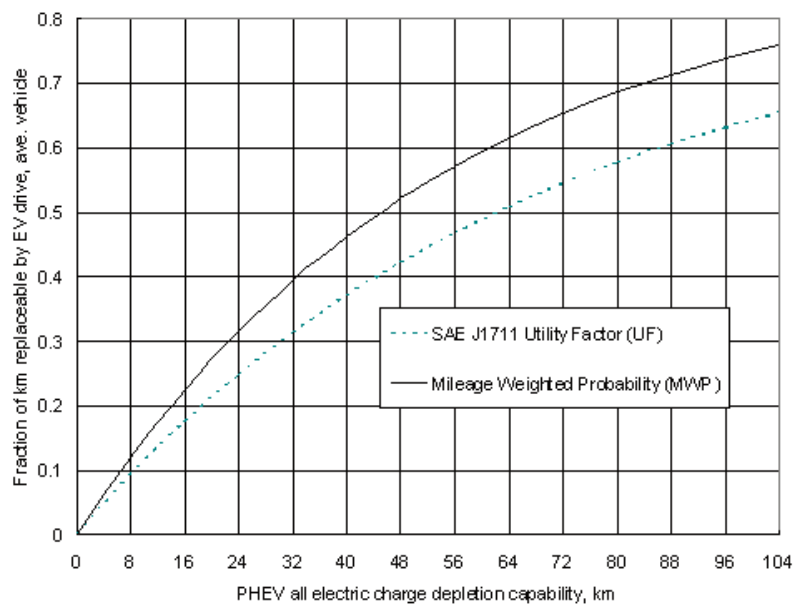

Figure 1: Utility factor and mileage weighted probability estimates of PHEV EV mode use 
Since that time, the 2001 National Household Travel Survey (NHTS) has been completed [3]. In this paper, we use the 2001 NHTS survey to try to think further about various implications of how consumers might drive PHEVs, how different PHEVs might be designed, under what cost effectiveness circumstances consumers might be most likely to purchase such vehicles, and how charging frequency, battery life, and battery cost might interact to affect cost effectiveness.

The assumption in the 2001 study and in the UF and MWP reference calculations is that the PHEV drives all electrically in charge depletion (CD) mode. However, testing of recent conversions of the Prius hybrid to a plug-in capability, using lithium-ion (li-ion) battery packs, has raised the issue that this assumption is not necessarily a correct assumption with respect to actual operation of PHEVs that will first be introduced into the market [4-7]. In fact, in most PHEVs, the design strategy may allow the engine to come on to assist in more extreme acceleration events, so "zero emissions" electric operation may be rare, unless required by regulation. Operation of a $\mathrm{PHEV}$ in which the battery depletes, but the engine comes on intermittently, is referred to as "blended mode" CD [7]. We define CD in all electric mode as CDE, and CD in blended mode as CDB. In the EnergyCS Prius [7], for example, test results on the urban dynamometer driving schedule (UDDS) indicate that full depletion of the battery pack is accomplished, at $54 \mathrm{~km}$, while full depletion on the highway (HWY) cycle occurs at $\sim 80$ kilometers. In both cases, gasoline (petrol) is consumed during the CD phase, but the consumption is well below the charge sustaining (CS) mode petrol consumption (55\% less on UDDS, 44\% HWY).

\section{COST AND MARKETABILITY - BLENDED MODE VS. ALL ELECTRIC RANGE}

Anderman [8] has recently questioned whether li-ion battery packs for PHEVs should be developed at a time when scarce research and engineering assets might better be focused only on development of high power liion batteries for HEVs. Anderman's argument is essentially that making li-ion batteries powerful enough to provide CDE capability instead of CDB capability will make the battery packs too costly and too bulky to fit into existing full hybrid vehicles. He uses the Toyota Camry hybrid as a reference point, arguing that development of a PHEV with only $32 \mathrm{~km}$ of all electric range (AER) for the Camry platform would eliminate $87 \%$ of the trunk. He estimated that a CDB version, which would use the same kWh of battery pack, but take $64 \mathrm{~km}$ to deplete, would use $62 \%$ of the trunk. Anderman's estimated power requirements for the 12 $\mathrm{kWh}$ CDB pack dropped by $71 \%$ relative to the $12 \mathrm{kWh}$ CDE pack.

The cost of power to run all electrically may indeed be significant. In 1999, Gaines and Cuenca [9] estimated the optimistic battery pack cost for a $35 \mathrm{kWh}$ battery pack designed for high energy to be $\$ 250 / \mathrm{kWh}$, while their estimate for a high power battery pack (kWh unspecified, $10010 \mathrm{~A}$-h cells) to be $\$ 1095 / \mathrm{kWh}$. This general trade off of rising $\$ / \mathrm{kWh}$ cost with rising W/Wh rating of a battery pack may well be generic, since it was also estimated in the 2001 EPRI report for nickel metal hydride (NiMH) batteries. At the recent Advanced Automotive Battery Conference, T. Miller of Ford [10] presented a non-linear plot of relative cost vs. W/Wh ratio for the battery. The relative cost index went from 1 to 5. Sharer et al [11] estimated the difference in W/Wh ratio as a PHEV capable of meeting the UDDS driving was provided a properly designed li-ion battery pack for 7 different AER values, from $12 \mathrm{~km}$ to $96 \mathrm{~km}$. The appropriate W/Wh ratio for the $12 \mathrm{~km}$ case was 15 , while for the $96 \mathrm{~km}$ case it was 2 . For an increase from $2 \mathrm{~W} / \mathrm{Wh}$ to $15 \mathrm{~W} / \mathrm{Wh}$, Miller estimated a $\$ / \mathrm{kWh}$ cost increase factor of about 4 . Clearly, the estimates of these experts imply the possibility of significant cost increases in the event that full function AER capability is designed into PHEVs with CD ranges of $\sim 12-32 \mathrm{~km}$.

Since battery cost is one of the leading deterrents to marketability of PHEVs, the CDE vs. CDB question is a very significant one. The added complication of an increase in volume (decrease in energy density) when the $\mathrm{W} / \mathrm{Wh}$ ratio rises has the potential to reduce marketability even more. Due to the fact that battery pack volume has been an issue even for HEVs, Santini and Vyas [12] have constructed a "hedonic" price coefficient for fraction of trunk room lost to battery packs. According to their estimates, significant losses of luggage space could reduce the value of a vehicle to the consumer by thousands of dollars.

One solution to the problem of loss of trunk space if converting an existing vehicle platform to a is to design a new vehicle to allow for space for a large battery pack and for an acceptable trunk. The Prius is an example of this approach, as is the Chevrolet Volt PHEV with 64 $\mathrm{km}$ of AER, a completely redesigned vehicle said to be coming to market in 2010 [13]. In fact, it appears that Toyota thought ahead in this regard, since the Prius has an empty space above the spare tire and below the trunk floor. In fact, in contrast to Anderman's estimates for the Camry, in the Prius PHEV conversions, the battery pack does not encroach into the trunk space (but it does in some cases interfere with access to the tire storage well).

In Table 1 we compare W/Wh used in different analyses. In Anderman's examples, he compares two pairs of PHEV powertrains with 6 , and $12 \mathrm{kWh}$ of battery pack. The CDE $16 \mathrm{~km}$ with $6 \mathrm{kWh}$ case is paired with a CDB $32 \mathrm{~km}$ with $6 \mathrm{kWh}$ case. For the former, the W/Wh ratio is 23 , while for the latter the ratio is four. For the CDE $32 \mathrm{~km}$ with $12 \mathrm{kWh}$ case, the W/Wh ratio estimated was 12 , while for the CDB $64 \mathrm{~km}$ with $12 \mathrm{kWh}$ case, the ratio was 3 . Though detailed 


\begin{tabular}{|l|c|c|c|c|c|}
\hline & Full HEV & PHEV16 & PHEV 32 & PHEV 64 & PHEV 96 \\
\hline Capable of CARB 2003 [19] AER requirements & & & & & \\
\hline Anderman for full capability < 10 sec 0-60 [8] & 14 & 23 & 12 & & \\
\hline Graham et al 2001 US06 [1] & 17 & & 9 & & 5 \\
\hline Sharer et al 2006 UDDS [11] & & 11 & 5.5 & 3 & 2 \\
\hline Not capable of CARB 2003 AER requirements & & & & & \\
\hline Anderman "blended" mode [8] & & & 4 & 3 & \\
\hline Hymotion Prius (CDB operation) [4] & & & $<=4^{*}$ & & \\
\hline Energy CS Prius (CDB operation) [4] & & & & $<=2^{*}$ & \\
\hline
\end{tabular}

Table 1: Estimates of W/Wh required for battery, various PHEV CD distance and acceleration abilities * Assumes no more than 21kW pack power, compatible with Prius HEV pack power estimates remain to be completed by our study team, based on the prior evaluations of $\$ / \mathrm{kWh}$ vs. W/Wh reviewed here, such W/Wh differences between CDE and $\mathrm{CDB}$ cases could reduce $\$ / \mathrm{kWh}$ costs by a factor of 3-5. The summary of a May 2006 "Discussion Meeting" at the U.S. Department of Energy provides no quantitative estimate of this trade-off, but the importance of the trade off was of great interest to participants. The executive summary states that, although "there was debate, most agreed that fuel economy, rather than all-electric range (AER), is the key metric for mass market consumers" [14].

The recent study by Kromer and Heywood [15] estimated the effects of reducing the amount of varying motor/battery $\mathrm{kW}$ vs. engine $\mathrm{kW}$, designed to accelerate comparably. Motor power for the four cases was $60,40,32$, and $23 \mathrm{~kW}$, respectively. Data for cases with the three most powerful electric motors are shown in Table 2. The highest power was estimated to provide UDDS all electric CD capability; the remaining cases were blended mode cases for the UDDS cycle. The UDDS capable PHEV, with the $60 \mathrm{~kW}$ motor, was estimated to operate in blended mode on the US06 cycle (Table 2, row 5). There are some inconsistencies in the published estimates with regard to US06 operations capability, which we have attempted to correct. Consider our interpretation of their data for fuel saving on the US06 cycle, as estimated in rows 5-7. Savings per $100 \mathrm{~km}$ amount to 3.32 for the $60 \mathrm{~kW}$ motor PHEV, motor/battery power successively in four cases with 3.07 for the $40 \mathrm{~kW}$ case, and 2.8 for the $32 \mathrm{~kW}$ case.

\begin{tabular}{|c|c|c|c|c|c|c|c|c|c|c|}
\hline Source & \begin{tabular}{|c|} 
Hybrid \\
Fraction \\
\end{tabular} & $\begin{array}{c}\text { Electric } \\
\text { Drive } \\
\text { Ability }\end{array}$ & $\begin{array}{c}\text { Engine } \\
\text { peak } \\
\text { kW }\end{array}$ & $\begin{array}{c}\text { Electric } \\
\text { drive } \mathrm{kW} \\
\text { limit }\end{array}$ & $\begin{array}{l}\text { Drive } \\
\text { cycle }\end{array}$ & $\begin{array}{l}\text { CS mode } \\
1 / 100 \mathrm{~km} \\
\end{array}$ & $\begin{array}{c}\text { CD } \\
\text { petrol } \\
\% \text { cut } \\
\end{array}$ & $\begin{array}{l}\mathrm{km} \text { to } \\
\text { Deple- } \\
\text { tion }\end{array}$ & $\begin{array}{c}\text { Vehicle } \\
\text { kg }\end{array}$ & Method \\
\hline $\begin{array}{c}\text { Graham et } \\
\text { al [1] }\end{array}$ & 0.46 & 〜S06 & 61 & 51.3 motor & UDDS & 5.72 & $100 \%$ & 34 & 1651 & Simulation \\
\hline $\begin{array}{c}\text { Graham et } \\
\text { al [1] }\end{array}$ & 0.46 & $\sim$ US06 & 61 & 51.3 motor & HWY & 4.97 & $100 \%$ & 35 & 1651 & Simulation \\
\hline $\mathrm{K} \& \mathrm{H}[15]$ & 0.55 & UDDS & 50 & 60 motor & UDDS & 2.5 & $100 \%$ & 60 & 1370 & Simulation \\
\hline $\mathrm{K} \& \mathrm{H}[15]$ & 0.55 & UDDS & 50 & 60 motor & HWY & 2.6 & $100 \%$ & 57 & 1370 & Simulation \\
\hline $\mathrm{K} \& \mathrm{H}[15]$ & 0.55 & UDDS & 50 & 60 motor & US06 & 3.9 & $-85 \%$ & 40 & 1340 & Simulation \\
\hline $\mathrm{K} \& \mathrm{H}[15]$ & 0.44 & $<$ UDDS & 50 & 40 motor & US06 & 3.89 & $-79 \%$ & 41 & 1345 & Simulation \\
\hline $\mathrm{K} \& \mathrm{H}[15]$ & 0.36 & $<$ UDDS & 58 & 32 motor & US06 & 3.94 & $-71 \%$ & 43 & 1350 & Simulation \\
\hline Vyas et al* & 0.44 & $\sim$ UDDS & 70 & 63 battery & UDDS & 4.73 & $-85 \%$ & 72 & 1566 & Simulation \\
\hline Vyas et al* & 0.44 & $\sim$ UDDS & 70 & 63 battery & HWY & 5.37 & $-81 \%$ & 68 & 1566 & Simulation \\
\hline $\mathrm{D} \& \mathrm{C}[7]$ & 0.3 & $<$ UDDS & 57 & $\begin{array}{c}21 \text { pack } 1 \sim \\
7 \text { pack } 2 \#\end{array}$ & UDDS & 3.55 & $-63 \%$ & 38 & 1378 & $\begin{array}{l}\text { Hymotion } \\
\text { Gen } 1 \text { test }\end{array}$ \\
\hline $\mathrm{D} \& \mathrm{C}[7]$ & 0.3 & $<$ UDDS & 57 & $\begin{array}{c}21 \text { pack } 1 \sim \\
7 \text { pack } 2 \#\end{array}$ & HWY & 3.72 & $-48 \%$ & 53 & 1378 & $\begin{array}{l}\text { Hymotion } \\
\text { Gen } 1 \text { test }\end{array}$ \\
\hline $\mathrm{D} \& \mathrm{C}[7]$ & 0.3 & $<$ UDDS & 57 & $\begin{array}{l}21 \text { pack } 1 \sim \\
15 \text { pack } 2 \#\end{array}$ & UDDS & 3.97 & $-63 \%$ & 40 & 1378 & $\begin{array}{l}\text { Hymotion } \\
\text { Gen } 2 \text { test }\end{array}$ \\
\hline $\mathrm{D} \& \mathrm{C}[7]$ & 0.3 & $<$ UDDS & 57 & $\begin{array}{l}21 \text { pack } 1 \sim \\
15 \text { pack } 2 \#\end{array}$ & HWY & 4.26 & $-46 \%$ & 50 & 1378 & $\begin{array}{l}\text { Hymotion } \\
\text { Gen } 2 \text { test }\end{array}$ \\
\hline $\mathrm{D} \& \mathrm{C}[7]$ & $\sim 0.30$ & $<\mathrm{UDDS}$ & 57 & $\begin{array}{l}\text { unknown } \\
\text { pack kW }\end{array}$ & UDDS & 3.72 & $-55 \%$ & 54 & 1433 & $\begin{array}{c}\text { Energy CS } \\
\text { test }\end{array}$ \\
\hline $\mathrm{D} \& \mathrm{C}$ [7] & $\sim 0.30$ & $<$ UDDS & 57 & $\begin{array}{l}\text { unknown } \\
\text { pack kW }\end{array}$ & HWY & 4.04 & $-44 \%$ & 80 & 1433 & $\begin{array}{c}\text { Energy CS } \\
\text { test }\end{array}$ \\
\hline
\end{tabular}

Table 2: Charge depleting petrol saving attributes of simulated and tested PHEVs as a function of hybrid fraction, selected studies

* This paper's estimates.

\#The Hymotion Prius leaves the original Ni-MH pack and adds a second Li-ion pack. The pack 2 controller limits kW. 
However, note that the savings are realized for more kilometers in the latter two cases. Considering the kilometers driven, the total petrol savings for the $60 \mathrm{~kW}$ motor PHEV is estimated to be 1.33 liters, 1.26 for the 40 case, and 1.20 for the $32 \mathrm{~kW}$ case. These computations make it appear that reduction in motor and battery power to produce an economical blended mode PHEV would not result in much sacrifice of fuel savings.

As far as the per kilometer percent reduction of petrol use during charge depleting mode is concerned, for the same hybrid fraction (0.44) our estimates are similar to those of Kromer and Heywood.

For the Hymotion Prius (a tested contemporary conversion, in contrast to the Kromer and Heywood simulations), the estimates of Duoba and Carlson for the UDDS indicate petrol savings of 2.2-2.5 liters per $100 \mathrm{~km}(63 \%)$ on the UDDS test cycle, and 1.8 to 1.9 liters per $\mathrm{km}$ (46 to $48 \%$ ) on the Highway cycle, somewhat less than the Kromer and Heywood blended mode 2030 vehicle simulations with a $32 \mathrm{~kW}$ motor. The nominal power of the Prius battery pack, according to Toyota, is $21 \mathrm{~kW}$. If we use the difference between Toyota's reported system peak kW of 82 for the Prius, and the $57 \mathrm{~kW}$ rating of the engine, this gives a hybrid fraction of 0.3 for the Prius. Thus, the real world tests imply that the reduction of hybrid fraction for a PHEV will reduce the petrol savings rate per kilometer in CD mode. The Hymotion Prius PHEV conversion retains the original nickel metal hydride pack in the Prius and adds a second Li-ion pack. The second pack only operates as an output device, storing grid electricity and passing it on to the vehicle electric machines, but never taking any regenerated Wh back from those machines during regenerative braking. An interesting point concerning the two Hymotion Prius vehicles tested is that we have determined that the $\mathrm{kW}$ that can be transferred from the existing packs to the Prius electric machines is limited by the "off the shelf" control equipment installed with the pack. Thus the $\mathrm{kW}$ that can be passed from the Li-ion pack to the wheels is quite limited. Nevertheless, testing does show that significant reductions in petrol consumption are obtained.

Duoba et al [16] have shown that the second generation Prius (2004 model year to the present) differs from the first by much earlier engine cutoff, following an acceleration event. In effect, the second generation Prius altered control strategy relative to the first, such that a much larger proportion of low speed cruise is done all electrically. It is likely that this feature of the control strategy allows the Hymotion Prius conversion to succeed largely by substituting Wh from the Hymotion pack (and grid) for on-board generated Wh from the Prius engine and generator, previously stored in the pack and otherwise retrieved during cruise operation. Cruise requires very little $\mathrm{kW}$ (often below $10 \mathrm{~kW}$ ). The stored on-board grid-derived $\mathrm{kWh}$ logically must also allow expansion of the proportion of cruise conditions that are run all electrically, creating a direct electric-for-engine substitution, in addition to the reduction of use of the roundabout gasoline powered "split" path from the engine to generator to pack to motor to wheels.

A difference between the simulations and the tests of the Prius PHEV conversions is a similarity of percent reductions in petrol use for the UDDS and Highway cycles in the simulations, in contrast to the lesser percent reductions on the highway in the case of the contemporary conversions. Alexander, Duvall, and Chhaya [17] discuss the trade-offs among different powertrain architectures. For the contemporary splithybrid, a problem with respect to high speed cruise operation is an inadequate amount of power to start the engine reliably and promptly in the event of demand for acceleration. According to the logic they present, at speeds common on U.S. Interstate highways, the existing split hybrid powertrain should not be operated all-electrically. This is not an inherent technical limitation, however. Our simulated PHEVs have addressed this limitation in their conceptual designs, thereby realizing similar percentage petrol savings for the HWY and UDDS cycles (Table 2).

The broad message from Table 2 is that the power available from battery packs and motors can drop dramatically relative to all electric operation power requirements, with relatively small penalties in fuel savings realized. Anderman had argued that the high costs and high volume requirements of high power batteries would make PHEVs undesirable. He did not, however, note that the ability to retain significant fuel savings even if the power level of battery packs were dropped would be an advantage in favor of PHEVs operating in blended mode. Another encouraging result worth verifying is the prediction by Kromer and Heywood that electric power requirements could be dropped by $50 \%$ (from 60 to $32 \mathrm{~kW}$ for rows $5-7$, with only a small effect on total distance to depletion. The advantage of rapid depletion is discussed later.

It appears that Anderman estimated power levels for his batteries for CDE cases as if he were trying to design a vehicle to completely assure that the engine would never be needed during CD mode, while the vehicle could accelerate as well as a standard vehicle when tested aggressively by auto enthusiast magazines. He used a battery peak $\mathrm{kW}$ rating of $140 \mathrm{~kW}$, a value somewhat more than the $118 \mathrm{~kW}$ rating of a Camry 4 cylinder engine, but well under the $200 \mathrm{~kW}$ rating of the V6. However, in everyday driving, even relatively aggressive driving, this amount of power is not used. For the EPRI 2001 study of PHEVs, the "US06" driving cycle, a cycle with hard accelerations and high top speeds, was used to size the battery [1]. In the simulations done, the engine did come on briefly during 
the most aggressive accelerations. For this driving cycle, the estimated W/Wh requirements for a U.S. midsize vehicle like the Camry were about 9 for a PHEV with $32 \mathrm{~km}$ of $\sim$ CDE. Sharer et al, in 2006, sizing the battery and motor for the much less aggressive UDDS driving cycle, obtained a required W/Wh value of a little over 5 as shown in Figure 2. Average acceleration requirements of a segment of the US06 cycle labeled the "city bag" for recent EPA on-road fuel consumption research are about 4 times as much as for the UDDS [18]. One can imagine how much such differences could cause battery $\mathrm{kW}$ ratings for AER to change. Anderman compared 25 and $40 \mathrm{~kW}$ blended mode cases to $140 \mathrm{~kW}$ all electric cases, a similar ratio. Fortuitously, it is peak, not average power that determines the battery and motor $\mathrm{kW}$ requirements to meet the requirements of these two driving cycles, so the ratio resulting from a comparison of Graham et al's US06 estimate [1], and Sharer et al's UDDS estimate [11] is about 2, not 4 . This ratio of estimated peak $\mathrm{kW}$ requirements is similar to the difference in the peak $\mathrm{kW}$ ratings of Camry V6 and 4 cylinder engines.

Figure 2 illustrates how the variation in optimized battery requirements for various PHEV designs estimated by Sharer et al affected estimates of battery mass per $\mathrm{kWh}$ and watts per watt-hour. Sharp increases occur when the AER range drops to $16 \mathrm{~km}$ and less.

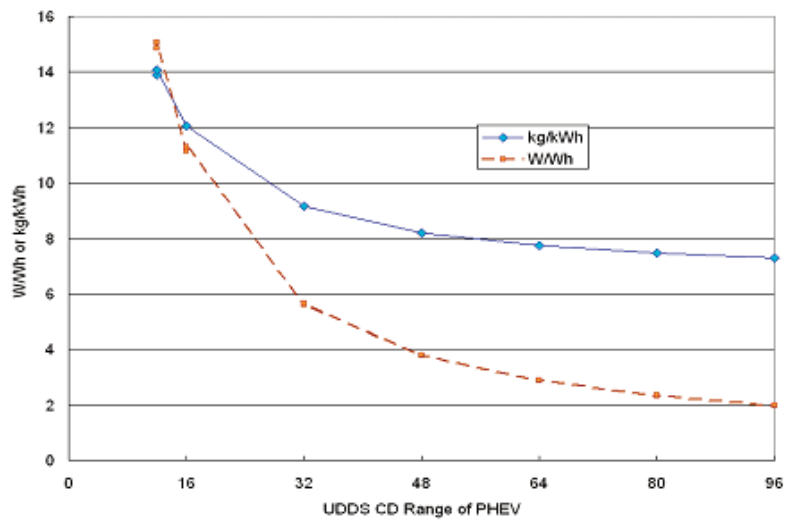

Figure 2: Variation of Modeled Li-ion Battery Attributes as PHEV UDDS CD Range Varies [11]

(LiNio.8Coo.15Alo.05 Graphite - "NCA Graphite" chemistry)

We see that the idea of AER or CDE is not a black and white idea. The way that the driver accelerates, and the speed requirements of the route traversed, in combination with the design choices made for the $\mathrm{kW}$ capability of the battery will dictate whether or not the engine comes on. An aggressive driver would cause many engine starts, while a passive driver might not cause any engine starts at all. There is also the possibility of having a regulatory requirement that PHEVs not be able to have the engine come on during charge depletion. Unfortunately, such a regulation could have the effect of causing drivers inclined to purchase higher power $\mathrm{PHEV}$ drivetrain to reject hybrids, reducing their marketability. Even for the passive drivers, the requirement that the PHEV engine stay off might require more battery $\mathrm{kW}$ than would otherwise be used in the vehicle, leading to higher costs, and reducing PHEV marketability.

It is always possible that $R \& D$ will make the difficulties discussed in this section moot. The recent presentation on the U.S. Department of Energy goals by Howell [18] allows one to make an educated guess concerning the energy density of battery packs, if the DOE PHEV goals are met. At an estimated W/Wh value of 10, approximately what Table 1 implies it would take in a PHEV32 to exceed US06 driving cycle requirements (aggressive driving), the DOE goals imply a target of about 10 liters of battery pack volume per $\mathrm{kWh}$. This is about half of what Anderman assumed is necessary.

Is this goal realistic? Note that Howell's presentation on the DOE Energy Storage program indicated ten research areas [18]. One of the ten was Li titanate/Mn spinel battery chemistry. In Sept. of 2006, Evan House of Altairnano Corporation asserted that the lithium titanate based anode being developed by his firm would be a "disruptive" battery technology, due to its much higher power than for other lithium based battery chemistries [19]. More recently, at this conference, Nelson et al, translating data for a battery chemistry with a lithium titanate anode (LiMn2O4-Li4Ti5O12, "NCA-graphite") characterized three battery packs for a high performance PHEV [20]. According to their estimates, this battery chemistry has the potential to be somewhat better than the DOE PHEV goals, when translated into terms of energy density. The battery pack volume required per nominal $\mathrm{kWh}$ of pack storage capability, according to Anderman, Nelson et al, and our translation of August 2007 DOE goals are shown in Figure 3. This plot implies that at least two of the chemistries among the several being worked on could diminish the importance of Anderman's argument.

It should be recognized that there may be several reasons for differences of estimates in Figure 3. In addition to the probability that chemistries assumed probably vary, cell design assumptions may also differ. Anderman may have used estimates based on a contemporary pack, using cylindrical cells. An alternative cell design that may be needed to enable more compact battery packs is the flat cell, often termed "prismatic". Nelson et al do not use the term cylindrical or prismatic in their paper to describe the cells modeled, but they do provide dimensions in terms of height, width and length, enough to make it clear that the cells are relatively flat, not cylindrical. Nelson et al also specify "air" as the cooling fluid. Relative merits of air vs. liquid cooling is also a factor in volume and reliability of battery packs, the choice of which is related to attributes of different battery chemistries. The overall point of Figure 3 is that there are promising options to deal with the concern that PHEV battery 
packs might require too much volume to be used easily in contemporary vehicle bodies. Techniques to reduce volume required per $\mathrm{kWh}$ will likely include, but not be limited to:

1. choice of battery chemistry

2. geometry of cell design

3. type of cooling suitable for the chemistry and/or cell design chosen

Figure 3 appears to illustrate a generic property of battery chemistries. As the ratio of energy to power increases, the suitability of a battery pack for use to store energy for electric drive, for a given vehicle acceleration capability, improves. Fortuitously, as this happens, it is also true that the volume required per $\mathrm{kWh}$ of energy stored drops, a tendency which makes it easier than it would otherwise be to adopt electric drive. A property that Figure 2 illustrates is that the power to energy $(\mathrm{Wh} / \mathrm{W})$ ratio drops (increases) rapidly as the first $32 \mathrm{~km}$ of CDE range are incorporated into PHEVs. Effects on costs as the properties of PHEV batteries change as a function of power to energy ratio and total $\mathrm{kWh}$ required for a given $\mathrm{PHEV}$ range remain to be estimated for the Li-ion chemistries being discussed here.

If the values among the lower liter per $\mathrm{kWh}$ points in Figure 3 can be put into practice, it should be possible to switch an advanced, high power lithium ion pack into the same space as in a contemporary HEV battery pack and have enough battery power and energy to meet the California Air Resources Board's (CARB) requirements for a PHEV16, obtaining credits [22]. Anderman states the present Camry battery pack requires 38 liters. DOE's goal for an HEV pack is 40 liters [18]. If we assume 10 liters per $\mathrm{kWh}$, a switch would result in 3.8 $\mathrm{kWh}$. For the lithium titanate cluster in Figure 3, that would be about $23 \mathrm{~W} / \mathrm{Wh}$ (from a version of Figure 2 using a linear Wh/W axis), which would mean about 87 $\mathrm{kW}$, which is in excess of Sharer et al's estimate of 69-75 $\mathrm{kW}$ required for a mid-size car to match the UDDS [11]. CARB's test procedures call for running the UDDS all electrically, for $16 \mathrm{~km}$ or more, to obtain partial zero emission vehicle credits (see next section). An efficient high power lithium titanate battery may be able to use $80 \%$ or more of nominal capacity (Nelson et al assume 90 [18]), so $3 \mathrm{kWh}$ would be available. To complete the required $16 \mathrm{~km}$ to obtain $\mathrm{CARB}$ credits, this would allow use of up to $188 \mathrm{Wh} / \mathrm{km}$, which is likely above the amount that would be required (see section 4). These computations and alternative estimates of volume needed per kWh suggest that Anderman's estimates were too pessimistic.

Nevertheless, the promise of lowering volume requirements per $\mathrm{kWh}$ as shown in Figure 3 does not completely eliminate the merit of Anderman's argument. Trying to make a sedan such as the Camry capable of $64 \mathrm{~km}$ of all-electric range still would not make sense, even with the more optimistic estimates presented here. At some point, requiring more and more CD range requires redesign of today's vehicles. Further, although these estimates show that the technical capability to put $\mathrm{kWh}$ in a small volume is probably better than Anderman assumed, they do not address the argument that more power in a battery also costs money.

\section{EFFECTS OF CD RANGE ON MARKETABILITY}

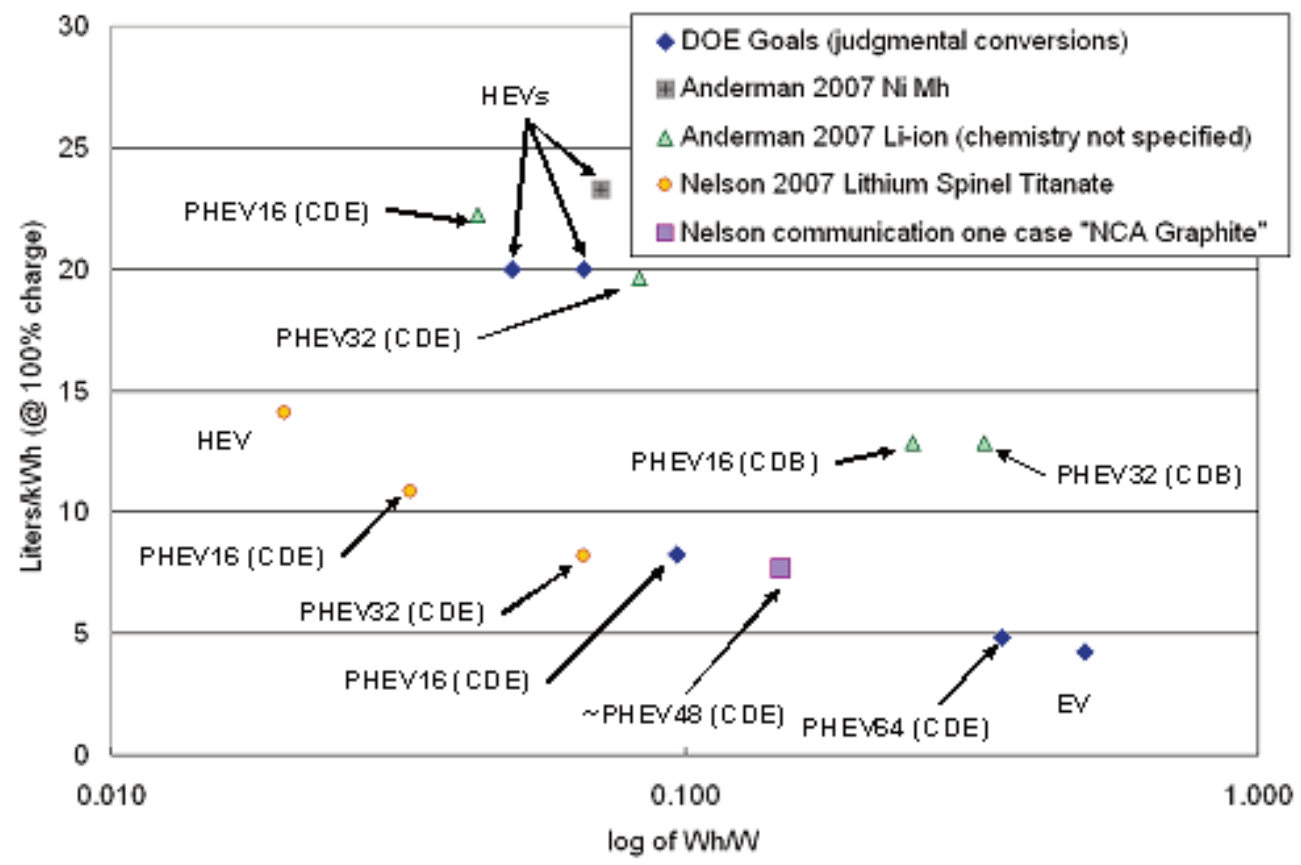

Figure 3: Liters of volume required per kWh of nominal pack capacity from various sources 
The engineering thinking imbedded in the MWP calculation (Figure 1) is that the more CD range $\mathrm{PHEV}$ powertrains have, the greater their potential to replace gasoline fueled kilometers with electrically fueled kilometers. The fallacy of this curve is that it fails to take into account cost effectiveness. Even if the U.S. Department of Energy's 2015 goals for a PHEV battery system of 5000 cycles, 15 years calendar life, and $\$ 250 / \mathrm{kWh}$ are met [18], the costs of batteries will remain a limiting factor for PHEV market success. The trade-offs just discussed imply that if this goal is met, it would be most likely to be met for a battery designed for a PHEV with CDB operation of $32-64 \mathrm{~km}$, where W/Wh ratios would be in the $3-5$ range.

At higher (and more costly - see section 2) W/Wh a vehicle produced might be able to garner a certification as a PHEV by the California Air Resources Board (CARB) [22]. CARB has specified a test that will require a PHEV in CDE mode to meet the UDDS speedtime trace, used in vehicle dynamometer tests to federally certify emissions and fuel economy on the U.S. Environmental Protection Agency "City" cycle. The UDDS has an average speed of $31 \mathrm{~km} / \mathrm{h}$, over a distance of $12 \mathrm{~km}$, attaining a top speed of $91 \mathrm{~km} / \mathrm{h}$. The other speed-time trace used in the U.S. to certify the Corporate Average Fuel Economy of light duty vehicles is the Highway (HWY) cycle, with an average speed of $77 \mathrm{~km} / \mathrm{h}$, for a distance of $16.3 \mathrm{~km}$, attaining a top speed of $96 \mathrm{~km} / \mathrm{h}$. In contrast, the US06 cycle, averaging 77 $\mathrm{km} / \mathrm{h}$, has a top speed of $129 \mathrm{~km} / \mathrm{h}$. In the CARB tests, the PHEV engine cannot be on in CD mode for the HWY cycle (i.e. CDE); for the US06 it is on (i.e. CDB). For the US06 a higher fraction of time than for the HWY cycle is spent accelerating and decelerating, and the average acceleration and deceleration rates are more than twice as high. The US06 has been evaluated by the U.S. EPA in comparison to real world driving in Kansas City [23]. It was found to be more extreme than normal driving, while the UDDS was found to be relatively passive. Instead of developing new tests, EPA constructed a weighting procedure to allow it to take advantage of considerable prior research based on these two cycles, but construct a representative average for its latest methodology for estimating on-road fuel consumption. This methodology has further increased estimates of fuel consumption, compared to the prior on-road adjustment factors [23]. In fuel consumption terms, the prior ratings were $11 \%$ upward from certification test values on the city (UDDS) cycle and $28 \%$ upward on the HWY cycle.

For the official CAFE manufacturer certification fuel consumption ratings, the U.S. Environmental Protection Agency uses the two tests conducted on the UDDS and HWY and constructs a weighted average. The average assumes $55 \%$ of driving is UDDS related driving and $45 \%$ is HWY related driving [23]. The test using the UDDS cycle includes cold start effects. It divides the test into three "bags", and includes a ten minute period between the second and third bag, in the official test. Our simulation model, PSAT, does not at this time allow us to address the effects of a cold start. Tests being evaluated for hybrids by SAE involve implementation of different procedures than are presently used for conventional vehicles, with more repetitions of the UDDS cycle likely. Procedures for testing the converted Prius PHEVs, which follow procedures recommended by SAE, currently involve repeated UDDS tests, and repeated HWY tests [7].

\section{ESTIMATING PETROL SAVINGS RATES RELATED TO DRIVING BEHAVIOR}

At the time of writing of this paper, we have completed simulations of three "split hybrid" PHEVs, one split hybrid HEV, a diesel and a conventional vehicle (Table 3). The "split hybrid" powertrain is similar to the Prius,

\begin{tabular}{|c|c|c|c|c|c|c|}
\hline Vehicle type $^{\wedge}$ & Diesel & Petrol & Power-split & Power-split & Power-split & Power-split \\
\hline Hybrid type & $\mathrm{CV}$ & $\mathrm{CV}$ & $\mathrm{HEV}$ & PHEV16+ & PHEV32+ & PHEV64+ \\
\hline Accessory power (W) & 400 & 400 & 220 & 220 & 220 & 220 \\
\hline Mass (kg) & 1445 & 1389 & 1516 & 1541 & 1566 & 1619 \\
\hline Engine peak kW & 85 & 97 & 68 & 69 & 70 & 72 \\
\hline Motor peak power $(\mathrm{kW})$ & & & 57 & 56 & 57 & 58 \\
\hline Generator peak power $(\mathrm{kW})$ & & & 54 & 55 & 56 & 57 \\
\hline Battery charge power $(\mathrm{kW})$ * & -1.3 & -1.3 & -32 & -71 & -71 & -71 \\
\hline Battery discharge power $(\mathrm{kW})$ * & 0.8 & 0.8 & 37 & 63 & 63 & 63 \\
\hline Battery capacity (kWh @ 100\%) & 0.8 & 0.8 & 1.4 & 4.2 & 8.4 & 17 \\
\hline UDDS fuel cons. (1/100km) & 5.05 & 6.42 & 3.08 & 3.34 & 3.38 & 3.47 \\
\hline HWY fuel cons. (1/100km) & 3.85 & 4.51 & 3.56 & 3.71 & 3.75 & 3.5 \\
\hline City on road fuel cons. (1/100km) & 6.89 & 8.56 & 4.51 & 4.64 & 4.67 & 4.62 \\
\hline HWY on-road fuel cons. (l/100km) & 5.51 & 6.4 & 5.13 & 5.32 & 5.37 & 5.04 \\
\hline
\end{tabular}

Table 3: Attributes of Vehicles Simulated

^ Every vehicle has the same drag area of 0.493 square meters (1.97 sq. m. frontal area times 0.25 coefficient of drag) and the same two rolling resistance equation coefficients $(\mathrm{Crr}=0.008$; $\mathrm{Crr} 2=0.00012)$

* For the PHEVs, the power rating is the 10 s power rating at $30 \%$ SOC. For the HEVs and conventional vehicles, this is the rated power at $70 \% \mathrm{SOC}$ 
Escape and Nissan Altima hybrids. Each vehicle is simulated as if it were based on a Prius-like "glider" (vehicle body), with the effects of different weights of powertrain components and battery packs taken into account, after designing all vehicles to meet the same set of performance requirements. This does not mean that each vehicle has exactly identical performance in all respects, but it does mean that its worst performance attribute just meets the binding constraint in the set of performance requirements. It may be better than required in other respects.

We estimate petrol (diesel) and, as applicable, kWh used per $\mathrm{km}$ and/or per test cycle for repeated UDDS and HWY cycles. The simulation is repeated enough times to assure that CD mode has ended and the vehicle has shifted to CS mode. For the PHEVs we estimate the reduction in petrol use per

$\mathrm{kWh}$ of electricity used, by comparing the petrol use during CD to what its value would be in CS mode. This provides us with an estimate of the petrol savings per $\mathrm{kWh}$ of battery depletion. The simulations estimate $\mathrm{kWh}$ into the battery terminals. We add an estimate of charger efficiency in converting wall plug alternating $120 \mathrm{~V}$ current to DC current into the battery (92\%, significantly higher than the 2001 EPRI report's $82 \%$ estimate [1], but consistent with values observed in recent Argonne tests).

From an economist's, or financial analyst's perspective, the fundamental question would be whether the purchase of a PHEV instead of an HEV or conventional vehicle would save enough fuel cost to pay for the added cost of the vehicle. The added costs will primarily be battery pack costs, though it will also be necessary to "beef up" some other powertrain components such as the electric machines and their cooling, and to pay for charger costs, particularly should high power batteries be used to provide CDE range and/or rapid recharge. The financial analyst' perspective may not be the perspective of a PHEV buyer, who may be interested in the technology for a number of reasons beyond just dollars and cents. However, for this paper, we take the financial analyst's perspective.

Table 4 presents our results for the three advanced 2015 PHEVs characterized by the PSAT model. These are based on the Prius vehicle body, with somewhat improved powertrain components. "Certification test" fuel use savings or costs for the two driving cycles simulated are relative to the base HEV characterized. In the headings we raise an issue with the labeling of a
PHEV as having a specified $\mathrm{CD}$ range. In fact, the CD range is likely to depend on how the vehicle is driven. It has been noted here, and by Kromer and Heywood [15] that on-road fuel consumption is considerably higher than certification test fuel consumption. We also developed a method of estimating the on-road fuel consumption penalty, from the latest EPA reports on available hybrid and diesel vehicles in the U.S. This is also discussed in the companion paper "Sorting Through the Many Total-energy-cycle Pathways Possible with Plug-in Hybrids", by Gaines et al. [24]

Figure 4 shows the results of our statistical investigation. Note that it was found that the on-road penalty was a function only of the certification test fuel consumption rating. Statistical tests for differences in equation intercept and slope for diesels and hybrids failed to find any statistical evidence of a difference among the drivetrain technologies. Admittedly, the sample was small, only 7 diesels, 17 hybrids, and 32 gasoline powertrains in the same vehicle bodies as for the hybrids and diesels. In the U.S., the myth that hybrids are penalized more than gasoline vehicles has been created by the deceptive choice of use of distance traveled per unit of fuel consumed. The effect of this choice is shown in Figure 4 by plotting the percent difference of on-road fuel consumption from certification fuel consumption. This shows that the reductions in onroad penalties are not as rapid as the reductions in certification fuel economy, leading to higher percentage penalties as fuel consumption declines. Needless to say, fuel efficient vehicles are penalized by expressing the changes between on-road and certification fuel consumption on a percentage, rather than absolute fuel 


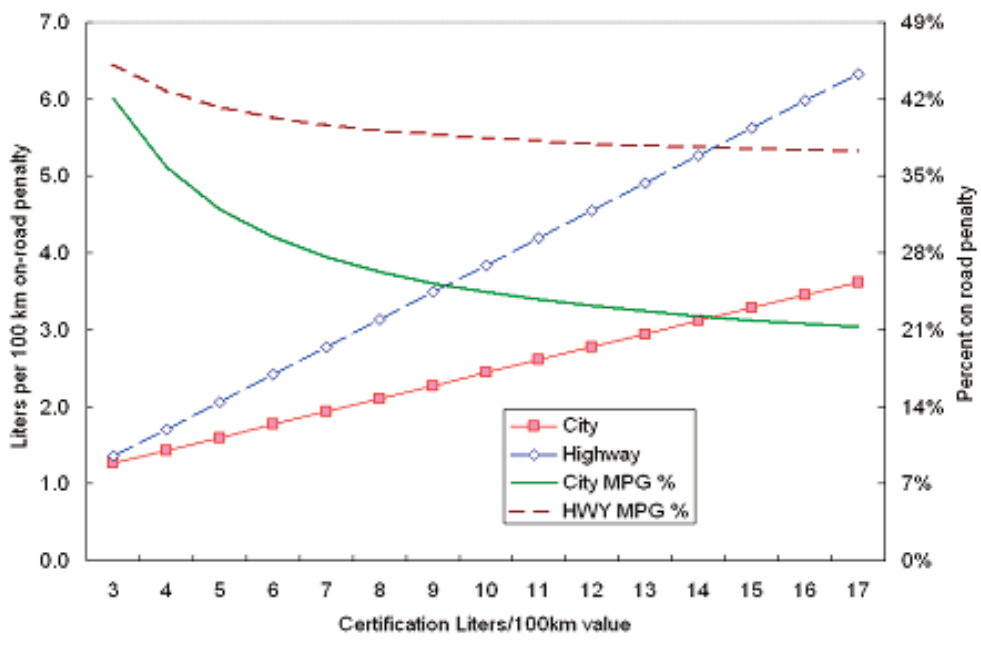

Figure 4: On-road penalty as a function of certification test value and cycle consumption change basis.

Table 5 shows our estimates of fuel consumption difference among the advanced 2015 vehicles that we simulated with PSAT, both before and after considering the effects of cold starts on city fuel consumption and then adding the penalty values as determined from the equations used to plot Figure 4.

An important point of interest is that the comparative advantage of the HEV is strongest for the urban, stop and go, UDDS cycle, while the comparative strength of the PHEV in CD mode is greatest against the competition in the HWY cycle. If this property holds true as simulated by us for 2015 PHEVs (and by Kromer and Heywood for 2030 [15], then such PHEVs could create an expanded opportunity for hybrid powertrains generally. If a customer's usual driving is much more like the HWY cycle than the UDDS cycle, then the marketer of the hybrid powertrain options can legitimately steer that customer toward the PHEV option, touting its ability to realize considerably greater savings than the $\mathrm{HEV}$ can accomplish in his/her type of driving. Another nuance is that, although the percentage savings on the UDDS cycle for the HEV is far higher than on the HWY cycle, the estimated volumetric savings rate per hour of $\mathrm{CD}$ driving the HEV on the highway are very similar. Also, since the rate of $\mathrm{Wh} / \mathrm{km}$ depletion for the PHEV is about the same on both the UDDS and HWY cycles, this means that the Wh used per unit time (and thus petrol saved per unit time) during the HWY cycle

(C) 2008 WEV Journal, pp. $x-x$ \# on a volumetric basis are far greater than for the UDDS cycle.

\section{DEPLETION: DISTANCE VS. TIME; PHEV ATTRIBUTES VS. DAILY TRAVEL}

\subsection{Interests of Individual Customers.}

There is a significant advantage of higher average speeds when the rate of depletion per mile is relatively constant, and the fuel saved per $\mathrm{kWh}$ depleted from the battery is relatively constant. Because batteries are and will be expensive, one does not want to purchase more battery $\mathrm{kWh}$ than can be effectively utilized. Thus, although it is technically true that a PHEV32 could replace the petrol kilometers of consumers driving between 0 and $32 \mathrm{~km}$ per day, the reality is that this would not be desirable. The problem of returning to the charger with the battery only partially discharged, required to be accounted for under the SAE J1711 subcommittee's procedures, certainly exists in this case. Customers frequently driving less than the $\mathrm{CD}$ range of a $\mathrm{PHEV}$ cannot realize the full benefits of the battery pack. Markel [25] observed that the benefits of a PHEV rise as daily trip length rises toward the $\mathrm{CD}$ range, then remains flat for many kilometers. For long trips, Markel estimated that the benefits drop, which is consistent with our estimates that the PHEVs usually have slightly worse fuel consumption in CS mode than does the HEV powertain in the same vehicle (Table 4).

The generic circumstance highlighted by Markel is illustrated conceptually in Figure 5, with the addition of a line representing the incremental cost of the PHEV in excess of the HEV. The fundamental point is that a customer who drives less than the CD distance will not

\begin{tabular}{|l|c|c|c|c|}
\hline & $\begin{array}{c}\text { HEV vs. } \\
\text { petrol }\end{array}$ & $\begin{array}{c}\text { Diesel } \\
\text { petrol }^{\#}\end{array}$ & $\begin{array}{c}\text { HEV petrol } \\
\text { vs. diesel }\end{array}$ & $\begin{array}{c}\text { PHEV32+ } \\
\text { in CDB vs. } \\
\text { HEV }\end{array}$ \\
\hline UDDS (hot) liters per 100 km & -3.34 & -1.37 & -1.97 & -2.3 \\
\hline UDDS (\% reduction, hot) & 52 & 21 & 39 & 75 \\
\hline UDDS hot liters per hr & -1.03 & -0.42 & -0.61 & -0.71 \\
\hline 'City" on-road liters/100 km & -4.05 & -1.67 & -2.38 & -3.47 \\
\hline City (\% on-road reduction) & 47 & 20 & 35 & 77 \\
\hline & & & & \\
\hline HWY liters per 100 km & -0.95 & -0.66 & -0.29 & $-2.52^{\wedge}$ \\
\hline HWY (\% reduction) & 21 & 15 & 8 & $71^{\wedge}$ \\
\hline HWY liters per hr & -0.73 & -0.51 & -0.22 & $-1.71^{*}$ \\
\hline Highway on-road liters/100km & -1.27 & -0.89 & -0.38 & $-1.8^{\wedge}$ \\
\hline Highway (\% on-road reduction) & 20 & 14 & 7 & $7 \mathbb{1}^{\wedge}$ \\
\hline
\end{tabular}

Table 5: HEV vs. conventional petrol and diesel cases, differences

$\wedge$ in CD mode. CD mode does not last a full hour, see note below.

* accounting for the $68 \mathrm{~km}$ CDB range of the PHEV $32+\mathrm{CD}$ does not continue $1 \mathrm{hr}$. 


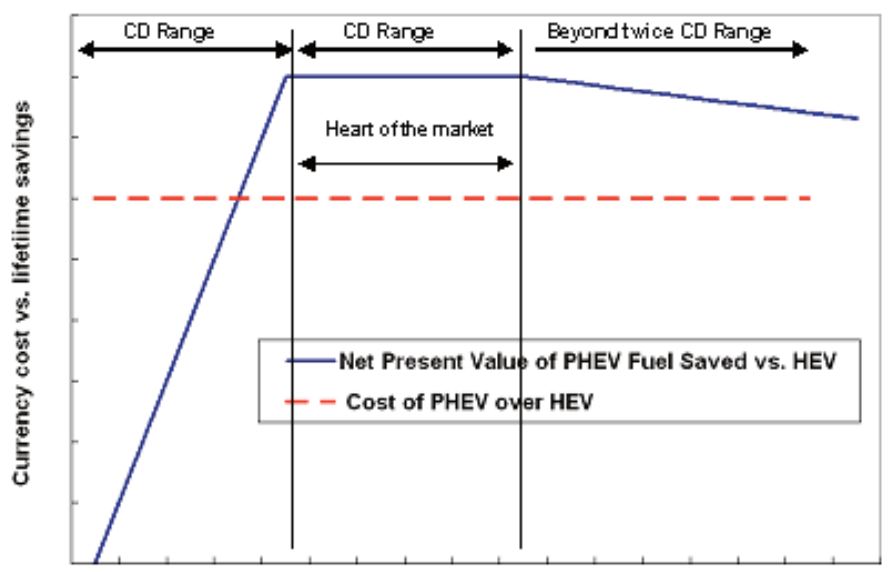

Daily Driving Distance of Potertial PHEV Dustomer

Figure 5: Illustration of Attractiveness of a PHEV With Respect to Driving Distance

realize the savings of a customer who does. Though the PHEV could meet nearly all needs of the former customer in CD mode, the customer might lose money because of purchase of more battery pack than they can effectively use. The heart of the market is the flat region noted by Markel, where savings are relatively constant. The slight drop-off in savings beyond this distance is due to the fact that the PHEV is heavier than an HEV, and perhaps the battery operates less efficiently in CS mode for a depleted PHEV than for an $\mathrm{HEV}$, which is illustrated for our simulations in Table 4. Of course, the further down the dotted PHEV incremental cost line is, the more customers realize savings by owning one. Still, those whose driving is less than the CD range of this particular PHEV might save more if offered a PHEV with a smaller, less costly battery pack.

\subsection{Estimating the Total National Technical Market vs. the Heart of the Market}

Using the NHTS, we divided the MWP shares of national kilometers that could be met in PHEV charge depleting mode into those that could be met for daily travel "up to" a given CD range, as well as for the initial parts of trips for daily travel that exceeded the CD range. Table 6 shows VKT contributed by vehicles traveling various distances per day and maximum percentage of VKT that can be transferred to electricity by various PHEVs. A $\mathrm{PHEV}$ that has an electric range longer than the distance traveled by a customer group (row) has potential to transfer all of that group's VKT to electricity. For customers that need to travel beyond a PHEV's electric range, only the first kilometers equal to its electric range can potentially be transferred to electricity. As a consequence, for a given distance category (say 16-32 $\mathrm{km}$ for example), the $\mathrm{km}$ that can be electrified by a PHEV with a CD range at the bottom end of the category ( $16 \mathrm{~km}$ in this case) is less than the total that could be achieved if each consumer could purchase a PHEV that exactly matched the daily average driving distance (and if the daily driving distance were actually a constant). Thus, for the example in question, our estimate of the miles convertible in PHEV mode within the $16-32 \mathrm{~km}$ category with a PHEV16 is $5.3 \%$, less than the hypothetical maximum of $8.1 \%$ implied by MWP and UF estimating procedures.

As discussed, the part that is "up to" the CD range is much less likely to be economic. Fortunately, we found that the majority of kilometers of travel that could be satisfied by a PHEV operating in CD mode - those in the "heart of the market" - were much greater for distances above ranges of 16 and $32 \mathrm{~km}$. For $16 \mathrm{~km}$ we estimated that $19.8 \%$ of daily $\mathrm{km}$, out of a theoretical total of $23.2 \%$ could be served by PHEVs usually completely depleting the battery pack. For the $32 \mathrm{~km}$ case the result was much better, at $29.2 \%$ of a theoretical total of $40.6 \%$. Concerning the share of the total technical market for which customers are found in the "heart of the market" daily distance range, the PHEV16 was the best case, with an $86 \%$ share, vs. $72 \%$ for the PHEV32, 50\% for the PHEV64, and 36\% for the PHEV96. Looked at from another perspective, the "heart of the market" percentages increase sharply up to the PHEV32 range, flatten out, then drop for the PHEV96. The drop for the PHEV96 implies that there

\begin{tabular}{|c|c|c|c|c|c|}
\hline Daily Travel Range of Vehicle & $\begin{array}{c}\text { Vehicle } \\
\text { Kilometers } \\
\text { Share in } \\
\text { NHTS 2001 }\end{array}$ & \multicolumn{4}{|c|}{$\begin{array}{c}\text { Maximum \% VKT on Electricity in Charge De- } \\
\text { pleting Operation (MWP) }\end{array}$} \\
\hline & & PHEV16 & PHEV32 & PHEV64 & PHEV96 \\
\hline Up to $16 \mathrm{~km}$ & $3.34 \%$ & $3.34 \%$ & $3.34 \%$ & $3.34 \%$ & $3.34 \%$ \\
\hline $16.01-32 \mathrm{~km}$ & $8.12 \%$ & $5.26 \%$ & $8.12 \%$ & $8.12 \%$ & $8.12 \%$ \\
\hline $32.01-64 \mathrm{~km}$ & $20.04 \%$ & $6.75 \%$ & $\mathbb{1 3 . 5 1 \%}$ & $20.04 \%$ & $20.04 \%$ \\
\hline $64.01-96 \mathrm{~km}$ & $16.72 \%$ & $3.36 \%$ & $6.73 \%$ & $13.46 \%$ & $16.72 \%$ \\
\hline Over $96 \mathrm{~km}$ & $51.78 \%$ & $4.46 \%$ & $8.91 \%$ & $17.82 \%$ & $26.73 \%$ \\
\hline Heart of the market & N/A & $19.83 \%$ & $29.15 \%$ & $31.28 \%$ & $26.73 \%$ \\
\hline Sum (total technical market) & $100.00 \%$ & $23.17 \%$ & $40.61 \%$ & $62.78 \%$ & $74.95 \%$ \\
\hline
\end{tabular}

Table 6: Share of National Kilometers Serviceable in 100\% CDE Mode, for Different PHEV Designs 
can be too much battery capacity put into a PHEV for national marketability purposes, according to this rough indicator.

The results for any single column in Table 6 apply to a case where one and only one $\mathrm{CDE}$ range is made available as an option for every new vehicle sold. Thus, if customers could only purchase an HEV or a PHEV16, the heart of the market sales could only electrify $19.8 \%$ of VKT. For the PHEV64, the maximum possible with a single CDE option would be $31.3 \%$, if batteries were relatively expensive. If the cost of batteries was cheap enough, and consumers would then buy more battery than they need, the percentage could rise significantly at the two longer ranges. Another approach, however, would be for automakers to offer a diversity of PHEV $\mathrm{CDE}$ range options. If customers had the choice of a PHEV16, 32, 64, or 96 and could purchase the option that was most attractive for them, then Table 6 implies that 5.3\% would select the PHEV16, $13.5 \%$ the PHEV32, 13.5\% the PHEV64, and 26.7\% the PHEV96, for a total "heart of the market" potential of $59 \%$. Again, if batteries were cheap enough, this total could also expand, since customers could afford to purchase more pack than needed for usual daily driving distances. This latter example shows the potential long-run market benefits of a diversity of PHEV ranges. It seems unlikely that any one vehicle platform would provide four alternative ranges as assumed in this discussion, but a couple per platform might be plausible in the long run. Also, a variety of platforms might be made available, some designed for the longer ranges, some for shorter ranges. Conceptually, this illustration is consistent with the inclusion of estimation of positive market share effects of make and model "diversity" in the Transitional Alternative Fuels Vehicle Model by Leiby and Rubin [26].

The estimates in Table 6 are based on the assumption that a PHEV will operate on $100 \%$ CDE mode. However, Anderman's suggested approach and the earlier mentioned tests of retrofitted Prius indicate that a blended CD mode may be more marketable, to the extent that cost is key Anderman assumed that a blended mode case would take twice as many kilometers to deplete a battery with the same $\mathrm{kWh}$ rating. Assuming that we hold the battery $\mathrm{kWh}$ capabilities of the 4 PHEVs of Table 6 constant, their revised CD range - the CDB range, would be twice as far. To make it clear these are "blended mode" PHEVs, we designate the mode by a "B" affixed to the distance to depletion. We assume that half as many $\mathrm{kWh}$ are used per $\mathrm{km}$. The values are tabulated in Table 7 .

Under the $50 \%$ blended CDB mode, short distance travel provides less VKT that can be serviced through electricity. However, total technical market VKT that can be serviced through electricity for PHEV32B in place of a PHEV16 is reduced by $3 \%$ only, from $23.2 \%$ to $20.3 \%$. Seventy two percent of these VKT are contributed by the heart of the market - vehicles traveling more than $32 \mathrm{~km}$ per day. The heart of the market drops somewhat more from the reference case in Table 6 , by $5 \%$ ( $20 \%$ vs. $15 \%)$.

The estimates in Table 7 are a pessimistic worst case if the vehicle simulation based estimates of Kromer and Heywood [15] are correct. They examined three different CDB cases, and one CDE case. For the case where they dropped peak motor power by over $62 \%$ relative to the CDE configuration, they got an increase of depletion distance of $24 \%$, far less than the doubling estimated by Anderman, when he dropped peak battery power by $71-82 \%$. While further investigation is desirable, the Kromer and Heywood estimates imply that a moderate level of power can lead to CDB mode $\mathrm{kWh} / \mathrm{km}$ depletion rates that will not be too far from those for PHEVs designed with high power motors and batteries, to operate in CDE mode.

Doubling PHEVB CDB range from $32 \mathrm{~km}$ to $64 \mathrm{~km}$ transfers $11 \%$ more technical market VKT to electricity.

\begin{tabular}{|c|c|c|c|c|c|}
\hline Daily Travel Range of Vehicle & $\begin{array}{c}\text { Vehicle } \\
\text { Kilometers } \\
\text { Share in } \\
\text { NHTS 2001 }\end{array}$ & \multicolumn{3}{|l|}{ MWP Under 50\% Blended CD operation } \\
\hline & & PHEV32B & PHEV64B & PHEV128B & PHEV192B \\
\hline Up to $16 \mathrm{~km}$ & $3.34 \%$ & $1.67 \%$ & $1.67 \%$ & $1.67 \%$ & $1.67 \%$ \\
\hline $16.01-32 \mathrm{~km}$ & $8.12 \%$ & $4.06 \%$ & $4.06 \%$ & $4.06 \%$ & $4.06 \%$ \\
\hline $32.01-64 \mathrm{~km}$ & $20.04 \%$ & $\mathbb{6 . 7 5 \%}$ & $10.02 \%$ & $10.02 \%$ & $10.02 \%$ \\
\hline $64.01-96 \mathrm{~km}$ & $16.72 \%$ & $\mathbb{3 . 3 6} \%$ & $6.73 \%$ & $8.36 \%$ & $8.36 \%$ \\
\hline $96.01-128 \mathrm{~km}$ & $12.27 \%$ & $\mathbb{1 . 7 6} \%$ & $3.52 \%$ & $6.14 \%$ & $6.14 \%$ \\
\hline $128.01-192 \mathrm{~km}$ & $14.19 \%$ & $\mathbb{1} .46 \%$ & $2.92 \%$ & $5.84 \%$ & $7.10 \%$ \\
\hline Over $192 \mathrm{~km}$ & $25.32 \%$ & $\mathbb{1} .24 \%$ & $2.48 \%$ & $4.95 \%$ & $7.4 .3 \%$ \\
\hline Heart of the market & N/A & $14.57 \%$ & $15.64 \%$ & $10.79 \%$ & $7.43 \%$ \\
\hline Sum (total technical market) & $100.00 \%$ & $20.30 \%$ & $31.39 \%$ & $41.04 \%$ & $44.77 \%$ \\
\hline
\end{tabular}

Table 7: Share of national kilometers serviceable in blended CD mode with $50 \% \mathrm{kWh} / \mathrm{km} \mathrm{CD}$ rate, for different PHEVB designs 
Extending PHEVB CDB range from $64 \mathrm{~km}$ to $128 \mathrm{~km}$ transfers less than $10 \%$ additional VKT and from 128 $\mathrm{km}$ to $192 \mathrm{~km}$ transfers only $4.7 \%$ of additional VKT. Note the phenomenon of decreasing effectiveness in expanding the technical market as CDB range is expanded. For the first $32 \mathrm{~km}, 20.3 \% / 32=0.63$ percentage points of total technical market potential per $\mathrm{km}$ of CDB range. For the next steps, the values are: $0.36 ; 0.15 ; 0.03$. From an economist's perspective, this demonstrates "diminishing returns" to technical market share for each $\mathrm{km}$ addition of CDB range.

The Hymotion Prius aftermarket PHEV depletes in blended mode in a little more than $32 \mathrm{~km}$ on the UDDS [4]. In other words, it is approximately a PHEV32B. During CDB on the UDDS, the Hymotion Prius uses about $40 \%$ of the petrol used in CS mode (i.e. reduction of 60\%). Similarly, Kromer and Heywood [15], simulating advanced blended PHEVs estimated that CDB petrol use was $36 \%$ of CS mode and less, for three blended mode cases examined. Note that both of these examples are less than the 50\% approximation (based on Anderman [8]) used for Table 7, thus Table 7 probably overstates the loss of market with use of blended mode.

\subsection{Disaggregating Market Segments}

We examined the 2001 NHTS to determine the average daily $\mathrm{km}$, average speed, and $\mathrm{km} / \mathrm{hr}$ as a function of population density. We separated our results by occupants of detached single family dwelling units vs. all other dwelling units, because detached single family units are a target market, due to the availability of garages and carports - convenient charging locations, usually with $120 \mathrm{~V}$ outlets. The data in Table 8 represents vehicles that were driven on the assigned travel day.

What we found is that the average hours per day driven is relatively constant, regardless of population density. As population density rose, average speed per day and average distance per day dropped. Thus, if speed is advantageous with respect to increasing the rate of depletion of $\mathrm{kWh}$, this means that sales of the PHEVs that we have characterized become more desirable as population density drops, because the odds of regular daily depletion, for any given CD range, rise.

\begin{tabular}{|l|c|c|c|c|}
\hline & $\begin{array}{c}\text { Share of vehicles } \\
\text { in density type }\end{array}$ & $\begin{array}{c}\text { Hours per } \\
\text { vehicle per day }\end{array}$ & $\begin{array}{c}\text { Average vehicle } \\
\text { speed (km/h) }\end{array}$ & $\begin{array}{c}\text { Kilometers per } \\
\text { vehicle per day }\end{array}$ \\
\hline All classes detached single & $79.00 \%$ & 1.24 & 50.5 & 62.7 \\
\hline All classes other & $21.00 \%$ & 1.28 & 47.1 & 60.1 \\
\hline$<386 /$ sq. km detached single & $84.20 \%$ & 1.27 & 55.2 & 70 \\
\hline$<386 /$ sq. km all other & $15.80 \%$ & 1.3 & 53.2 & 68.9 \\
\hline $386-1544$ sq. km detached single & $80.20 \%$ & 1.21 & 47.1 & 57.1 \\
\hline $386-1544$ sq. km all other & $19.80 \%$ & 1.24 & 47.8 & 59.3 \\
\hline $1544-3860$ sq. km detached single & $72.90 \%$ & 1.19 & 43.6 & 52 \\
\hline $1544-3860$ sq. km all other & $27.10 \%$ & 1.25 & 42.8 & 53.5 \\
\hline $3860-9650 /$ sq. km detached single & $46.50 \%$ & 1.31 & 37.5 & 49.2 \\
\hline $3860-9650 /$ sq. km all other & $53.50 \%$ & 1.32 & 38.1 & 50.3 \\
\hline$>9650$ sq. km detached single & $20.50 \%$ & 1.41 & 32.4 & 45.8 \\
\hline > 9650 sq. km all other & $79.50 \%$ & 1.4 & 33.5 & 46.9 \\
\hline
\end{tabular}

Table 8: Characteristics of U.S. Daily per Vehicle Driving vs. Dwelling Unit Type and Density

\begin{tabular}{|c|r|r|}
\hline & $\begin{array}{c}\text { Share of Occupied } \\
\text { Housing Units }\end{array}$ & $\begin{array}{c}\text { \% With Garage or } \\
\text { Carport }\end{array}$ \\
\hline Type of Housing Unit & & $79.30 \%$ \\
\hline New Construction (<=4 Years) & $6.50 \%$ & $30.30 \%$ \\
\hline Manufactured/ Mobile Homes & $5.70 \%$ & $37.90 \%$ \\
\hline With Physical Problems & $82.40 \%$ & $65.80 \%$ \\
\hline All Other & & $49.00 \%$ \\
\hline Geographic Location (Census Region) & $18.70 \%$ & $72.00 \%$ \\
\hline Northeast & $22.90 \%$ & $54.80 \%$ \\
\hline Midwest & $36.50 \%$ & $77.60 \%$ \\
\hline South & $21.90 \%$ & \\
\hline West & & $53.70 \%$ \\
\hline Type of Location & $29.20 \%$ & $69.10 \%$ \\
\hline MSA - Central City & $48.50 \%$ & $60.40 \%$ \\
\hline MSA - Suburbs & $22.30 \%$ & \\
\hline Outside MSA & & \\
\hline
\end{tabular}

Table 9: Housing Unit Characteristics from AHS 2005 
Fortunately, it is also true that, as metropolitan area population density drops, the share of detached single family homes, (and presumably the share of dwelling units with garages) rises.

Access to a facility for charging a PHEV from the grid is essential to take full advantage of its capabilities. The 2005 American Housing Survey (AHS) provides a summary of housing units that have a garage or carport. The AHS data showed that $76 \%$ of the occupied housing units were single family structures and $63 \%$ of all occupied housing units had access to a garage or a carport. Newer housing units, built in the last four years, were more likely to have a garage or a carport. The 2005 AHS showed that 5.5\% of the housing units were built in the last four years. Table 9 summarizes the AHS 2005 data. Among the four Census regions, the Midwest and West regions have the higher percents of housing units with a garage or carport. The South region has the largest share of housing units, 59\% more than the second largest, the Midwest region. However, only $54.8 \%$ of the housing units in the South have garage or carport.

An important finding is that the suburbs of metropolitan statistical areas (MSAs) have a considerably higher percentage of garages than do central cities, or areas outside of MSAs.

\section{ILLUSTRATIONS OF POSSIBLE LIFETIME SAVINGS IN THE HEART OF THE MARKET}

We have implied that the heart of the market for PHEVs should be among suburban households. We have shown that the heart of the market should be for vehicles that are normally driven beyond the CD range of the PHEV. However, we have also noted that the cost of batteries will deter purchase of high amounts of CD range. Further, the volume taken from the usable space within the vehicle by the batteries has been argued to be a concern that should also limit the size of battery packs put into modified versions of existing vehicle bodies even in a vehicle such as the Prius. Thus, since space and cost will limit the size of battery packs, the benefits of batteries will be confined to use over distances of perhaps 20 to $60 \mathrm{~km}$. We have shown that our PHEV attributes estimates imply that consumers whose annual driving is well beyond the $\mathrm{CD}$ range of a $\mathrm{PHEV}$ would be penalized with respect to fuel consumption compared to purchase of a $\mathrm{HEV}$ without a plug-in option. Generically, we expect the most attractive average daily distances driven to be between one unit of charge depleting distance and about two. Driving on average days well beyond the CD range would mean that those days with less than average miles would still be likely to go beyond the PHEV CD range. For such customers the battery would be very effectively used.

In the next three tables we construct illustrative estimates of the potential vehicle lifetime fuel cost reductions attainable for a PHEV32 customer in the "heart of the PHEV market". We assume that this customer is a suburbanite who will park and charge the PHEV overnight in a garage, who on average drives twice the $\mathrm{CD}$ distance, about $64 \mathrm{~km} /$ day. In the first two cases we examine, the charger is the least expensive available, between 1 and $2 \mathrm{~kW}$, using $120 \mathrm{~V}$, and installed in the garage. We first evaluate the potential savings for this customer as if a PHEV32, capable of 32 $\mathrm{km}$ of AER, had been purchased (Table 10). We then consider the possibility that this customer purchases instead a PHEV64B with the same $\mathrm{kWh}$ and thus charged by the same charger using the same amount of time in the garage (Table 11). However, with this vehicle, twice the miles must be driven to deplete the overnight charge. With this option the customer has a bit more trouble using the $\mathrm{kWh}$ charging capability in the garage, and uses kWh at a slightly lower rate. The battery lasts a bit longer in calendar life, due to a somewhat lower rate of CD cycling. Our assumption is that these two cases involve a charger in the garage and off-board the vehicle. This consumer is likely to consistently charge overnight, and would be likely to consider opting for an "off-peak" electric rate allowing cheaper charging at night in exchange for higher daytime charges

For the last case (Table 12) we return to the assumption that the customer purchases a PHEV32 with AER and assume that the customer has an option of purchasing an on-board charger capable of more rapid charging than for the former cases. The house electric circuit is assumed to be compatible with high rate charging from a garage, so that it is easier for this customer to recharge during the day, perhaps on weekends. The charger also allows charging from a $120 \mathrm{~V}$ plug. An extension cord is part of the charging package. This customer can plug-in to outdoor outlets whenever a friend or business allows him to do so.

In all cases, the useable $\mathrm{kWh}$ of the battery pack are about $5.1 \mathrm{kWh}$ from the battery terminals, which requires about $5.5 \mathrm{kWh}$ from the plug/grid. At $\$ 0.10$ per $\mathrm{kWh}$ it costs this customer $\$ 0.55$ per fill-up, or it costs friends or businesses a maximum of $\$ 0.55$ to allow him to fully charge at their location free (Table 12). Admittedly an approximation, our fuel savings estimates assume 0.268 liters of fuel saved per wall plug $\mathrm{kWh}$ of electricity purchased for all three cases.

In these illustrations we estimate the net present value (NPV) of fuel savings for PHEVs which have similar liters per $\mathrm{kWh}, \mathrm{km}$, and hour of use to those we have characterized. The NPVs are compared to battery pack costs, at different $\$ / \mathrm{kWh}$ values. The estimates in Table 10-12 are based on annual vehicle use by vintage reported by the National Highway Traffic Safety Administration (NHTSA) within the U.S. Department of Transportation [27]. 


\begin{tabular}{|c|c|c|c|c|c|}
\hline \multirow{2}{*}{$\begin{array}{c}\text { Electricity Cost } \\
\text { cents/kWh }\end{array}$} & \multirow{2}{*}{$\begin{array}{l}\text { Petrol Cost } \\
\text { cents/Liter }\end{array}$} & \multicolumn{2}{|c|}{ Discount Rate 6\% } & \multicolumn{2}{|c|}{ Discount Rate 8\% } \\
\hline & & $\begin{array}{l}\text { Battery Life } \\
3,600 \text { Cycles }\end{array}$ & $\begin{array}{l}\text { Battery Life } \\
4,500 \text { Cycles }\end{array}$ & $\begin{array}{l}\text { Battery Life } \\
3,600 \text { Cycles }\end{array}$ & $\begin{array}{l}\text { Battery Life } \\
4,500 \text { Cycles }\end{array}$ \\
\hline \multicolumn{6}{|l|}{ U.S. } \\
\hline 9.45 & 79.3 & $\$ 1,570$ & $\$ 1,830$ & $\$ 1,440$ & $\$ 1,640$ \\
\hline 9.45 & 105.7 & $\$ 2,600$ & $\$ 3,030$ & $\$ 2,380$ & $\$ 2,710$ \\
\hline 5 & 79.3 & $\$ 2,330$ & $\$ 2,710$ & $\$ 2,130$ & $\$ 2,430$ \\
\hline 5 & 105.7 & $\$ 3,360$ & $\$ 3,900$ & $\$ 3,070$ & $\$ 3,500$ \\
\hline \multicolumn{6}{|l|}{ France $^{\S}$} \\
\hline 12.57 & 162.3 & $\$ 4,410$ & $\$ 5,130$ & $\$ 4,040$ & $\$ 4,600$ \\
\hline \multicolumn{6}{|l|}{ Sweden $^{\S}$} \\
\hline 12.16 & 158.1 & $\$ 4,310$ & $\$ 5,020$ & $\$ 3,950$ & $\$ 4,500$ \\
\hline
\end{tabular}

Table 10: Net Present Value of Fuel Savings for PHEV32 in CDE Operation Under Two Different

Fuel Costs $\dagger$, Discount Rates, and Battery Lifetimes.

${ }^{\dagger}$ Petrol liters saved: 5,260 for battery life of 3,600 cycles and 6,610 for battery life of 4,500 cycles.

${ }^{\S}$ At 72.02 U.S. cents per Euro.

We assumed that $15 \%$ of the annual VKT will be traveled when the PHEV will not be charged. The remainder of VKT were assumed to be driven over 300 days with the PHEV fully charged once each day. The base vehicle to which the PHEV is compared is a charge sustaining HEV that gives $21.1 \mathrm{~km}$ per liter of gasoline (uses $0.0475 \mathrm{~L} / \mathrm{km}$, equivalent to $49.8 \mathrm{mpg}$ ). Although EPA has observed HEV owners in Kansas City [23], finding that they drove more passively than most drivers, we assume that the early owners of PHEVs drive like an average driver, and therefore consume $\mathrm{kWh}$ and fuel at an average on-road rate consistent with EPA's latest on-road estimating procedures. The PHEV is assumed to use $159 \mathrm{Wh} / \mathrm{km}$ of stored energy (i.e. from charger to the battery pack). We applied a charger efficiency of $92 \%$ while computing electricity use from electric grid. The result is an estimated $173 \mathrm{Wh} / \mathrm{km}$ from the wall plug for the AER cases. We used U.S. average residential electricity cost of 10 cents/kWh and an alternative "off-peak" cost of 5 cents/kWh. Petrol costs of $\$ 0.793$ and $\$ 1.057$ per liter ( $\$ 3$ and $\$ 4$ per U.S. gallon) were used. Two European petrol and electricity price cases are also tabulated. The annual kilometers traveled assumptions remain the same as for the U.S. A smaller proportion of Europeans would drive this many kilometers, since Europeans generally drive fewer kilometers per year. However, for Belgium, the recent PHEV analysis by Clement-Nyns, Van Reusel and Driesen [28] indicates that diesel owners in Belgium travel more miles on average than the typical U.S. passenger car. The European electricity prices per $\mathrm{kWh}$, in Euros, are 0.0905 for France and 0.0876 for Sweden. Petrol price, per liter, in France is taken as 1.169 Euros and in Sweden 1.139 Euros.

For the PHEV64B estimates in Table 11 the full PHEV range is not utilized after the first four years of vehicle's life and consequently it is possible that battery would last longer than 3,600/4,500 charging episodes assumed in the analysis.

For Table 12, we assume that frequent charging would be equivalent to depleting 1.5 cycles per day. The effect of frequent charging is to use up battery cycles at a faster rate. Since a vehicle is driven more during its early years, more VKT are transferred to electricity. The discounted values of the savings are higher.

\section{BATTERY COST}

\begin{tabular}{|c|c|c|c|c|c|}
\hline \multirow{2}{*}{$\begin{array}{c}\text { Electricity Cost } \\
\text { cents/kWh }\end{array}$} & \multirow{2}{*}{$\begin{array}{l}\text { Petrol Cost } \\
\text { cents/Liter }\end{array}$} & \multicolumn{2}{|c|}{ Discount Rate 6\% } & \multicolumn{2}{|c|}{ Discount Rate 8\% } \\
\hline & & $\begin{array}{l}\text { Battery Life } \\
3,600 \text { Cycles }\end{array}$ & $\begin{array}{l}\text { Battery Life } \\
4,500 \text { Cycles }\end{array}$ & $\begin{array}{l}\text { Battery Life } \\
3,600 \text { Cycles }\end{array}$ & $\begin{array}{l}\text { Battery Life } \\
4,500 \text { Cycles }\end{array}$ \\
\hline \multicolumn{6}{|l|}{ U.S. } \\
\hline 9.45 & 79.3 & $\$ 1,380$ & $\$ 1,550$ & $\$ 1,270$ & $\$ 1,400$ \\
\hline 9.45 & 105.7 & $\$ 2,290$ & $\$ 2,570$ & $\$ 2,110$ & $\$ 2,330$ \\
\hline 5 & 79.3 & $\$ 2,060$ & $\$ 2,310$ & $\$ 1,900$ & $\$ 2,090$ \\
\hline 5 & 105.7 & $\$ 2,970$ & $\$ 3,330$ & $\$ 2,740$ & $\$ 3,020$ \\
\hline \multicolumn{6}{|l|}{ France ${ }^{\S}$} \\
\hline 12.57 & 162.3 & $\$ 3,940$ & $\$ 4,370$ & $\$ 3,590$ & $\$ 3,960$ \\
\hline \multicolumn{6}{|l|}{ Sweden ${ }^{\S}$} \\
\hline 12.16 & 158.1 & $\$ 3,810$ & $\$ 4,270$ & $\$ 3,510$ & $\$ 3,870$ \\
\hline
\end{tabular}

Table 11: Net Present Value of Fuel Savings for PHEV64B in 50\% Blended CD Operation

Under Two Different Fuel Costs ${ }^{\dagger}$, Discount Rates, and Battery Lifetimes

† Petrol liters saved: 4,570 for battery life of 3,600 cycles and 5,460 for battery life of 4,500 cycles.

$\S$ At 72.02 U.S. cents per Euro.

(C) 2008 WEV Journal, pp. $x-x$ 


\begin{tabular}{|c|c|c|c|c|c|}
\hline \multirow{2}{*}{$\begin{array}{c}\text { Electricity Cost } \\
\text { cents/kWh }\end{array}$} & \multirow{2}{*}{$\begin{array}{l}\text { Petrol Cost } \\
\text { cents/Liter }\end{array}$} & \multicolumn{2}{|c|}{ Discount Rate $6 \%$} & \multicolumn{2}{|c|}{ Discount Rate $8 \%$} \\
\hline & & $\begin{array}{l}\text { Battery Life } \\
\text { 3,600 Cycles }\end{array}$ & $\begin{array}{l}\text { Battery Life } \\
4,500 \text { Cycles }\end{array}$ & $\begin{array}{l}\text { Battery Life } \\
\text { 3,600 Cycles }\end{array}$ & $\begin{array}{l}\text { Battery Life } \\
4,500 \text { Cycles }\end{array}$ \\
\hline \multicolumn{6}{|l|}{ U.S. } \\
\hline 9.45 & 79.3 & $\$ 1,840$ & $\$ 2,190$ & $\$ 1,740$ & $\$ 2,030$ \\
\hline 9.45 & 105.7 & $\$ 3,020$ & $\$ 3,580$ & $\$ 2,840$ & $\$ 3,330$ \\
\hline 5 & 79.3 & $\$ 2,680$ & $\$ 3,190$ & $\$ 2,530$ & $\$ 2,960$ \\
\hline 5 & 105.7 & $\$ 3,860$ & $\$ 4,580$ & $\$ 3,640$ & $\$ 4,250$ \\
\hline \multicolumn{6}{|l|}{ France $^{\S}$} \\
\hline 12.57 & 162.3 & $\$ 5,100$ & $\$ 6,060$ & $\$ 4,810$ & $\$ 5,630$ \\
\hline \multicolumn{6}{|l|}{ Sweden $^{\S}$} \\
\hline 12.16 & 158.1 & $\$ 4,990$ & $\$ 5,920$ & $\$ 4,700$ & $\$ 5,500$ \\
\hline
\end{tabular}

Table 12: Net Present Value of Fuel Savings for PHEV32 in 100\% CDE Operation

Involving Frequent Charging Under Two Different Fuel Costs ${ }^{\dagger}$, Discount Rates, and Battery Lifetimes

+ Petrol liters saved: 5,410 for battery life of 3,600 cycles and 6,770 for battery life of 4,500 cycles.

$\S$ At 72.02 U.S. cents per Euro.

order to put the NPV fuel savings estimates into perspective, we need an estimate of battery costs. Retail prices of li-ion consumer cells dropped dramatically over the last few years, to a point where they recently dropped below the prices of Ni-MH and Nickel cadmium cells, at a cost of $\sim \$ 480 / \mathrm{kWh}[29]$. Since these costs involve packaging for sale to final consumers in relatively small quantities, it seems reasonable to assume that cells purchased in volume by auto manufactures and/or suppliers would cost less. However, the average consumer cells are presently unacceptable with respect to achievement of automotive requirements. Recognizing that it is a considerable challenge, we use an estimate of $\$ 500$ per useable battery pack kWh as a reference target for $2015 \mathrm{PHEV}$ battery pack costs. We note that the DOE goal is to achieve a cost per useable pack $\mathrm{kWh}$ of $\$ 250$ [18], so we also discuss results if this goal is met. We have argued that this goal is more likely to be attainable for a blended mode PHEV.

An important nuance is that it is the incremental cost of the PHEV pack, replacing the HEV pack (i.e. the difference between the two), which determines the incremental cost of the PHEV to the consumer. The base HEV, relative to which we estimated NPV of PHEV fuel savings, is a power-assist parallel HEV that operates only in the CS mode. We assume that it has a $30 \mathrm{~kW}$ battery pack, where the $\mathrm{kW}$ rating is based on power sustainable for 10 seconds. The battery pack for such a vehicle is estimated to cost nearly $\$ 3,000$ now, for a $25 \mathrm{~kW}$ rated pack, which is $\$ 120 / \mathrm{kW}$ [30]. Through increases in production volume, further research, and learning by doing, the cost per $\mathrm{kW}$ sustainable for 10 seconds in a battery pack designed for high power (HEV pack) is expected to be reduced to $\$ 30 / \mathrm{kW}$ by 2010 , while the long-term DOE goal is to reduce it to $\$ 20 / \mathrm{kW}$ [30].

Our use of $159 \mathrm{Wh} / \mathrm{km}$ of stored energy for the PHEV necessitates a useable battery capacity of $5.1 \mathrm{kWh}$ for a $32 \mathrm{~km}$ electric range. The battery manufacturers use

nominal rated capacity while specifying battery energy storage capacity. We assume that $70 \%$ of the nominal rated capacity will be useable by a PHEV. The resulting nominal rated capacity will be $7.3 \mathrm{kWh}$. As mentioned earlier, our reference assumption is a $\$ 500$ per $\mathrm{kWh}$ price for a PHEV battery pack for an AER PHEV, based on rated kWh. A PHEV battery pack will have other components increasing the battery pack cost by nearly $\$ 700$ [31]. A PHEV will also require such support hardware as an off-board charger and electrical catalyst heater costing $\$ 300$. The resulting total cost of the pack, supplied by a hypothetical company providing pack systems to Original Equipment Manufacturers (OEMs) would be $\$ 4,650$. At $\$ 250$ per $\mathrm{kWh}$ the cost of delivery to an OEM by a supplier would be $\$ 2,825$. The base HEV battery pack and related equipment is estimated to cost $\$ 1,600(\$ 900+\$ 700)$ at $\$ 30 / \mathrm{kW}$ and $\$ 1,300$ at the DOE goal of $\$ 20 / \mathrm{kW}$.

The cost to consumers would be higher, accounting for warrantee costs and OEM overhead. The multiplier for converting OEM cost to retail price equivalent ranges from 1.15 to 1.5. Graham et al [1] added fixed amounts and used a multiplier of 1.15 to evaluate two sets of alternative retail price equivalent while reference [31] used a multiplier of 1.35. Thus, with 0.15-0.35 alternative OEM-to-consumer mark-ups, the PHEV battery pack retail price equivalent at $\$ 500$ per $\mathrm{kWh}$ would range from $\$ 5,350$ to $\$ 6,280$. At a price of $\$ 250$ per $\mathrm{kWh}$ it would be $\$ 3,250-\$ 3,815$. The corresponding battery cost for the base HEV would be $\$ 1,840-\$ 2,160$ at $\$ 30 / \mathrm{kW}$ and $\$ 1,495-\$ 1,755$ at $\$ 20 / \mathrm{kW}$. The net difference for the PHEV 32 relative to the HEV0 would be $\$ 3,510-\$ 4,120$ at $\$ 500 / \mathrm{kWh}$ and $\$ 1,755-\$ 2,060$ at $\$ 250 / \mathrm{kWh}$.

These are rough estimates, based on the literature and on DOE goals. They are preliminary and are intended to be illustrative. To repeat, the lower of the two cost estimates should be thought of as more probable in a blended mode PHEV, while the higher of the two should 
be thought of as more likely for a PHEV with AER.

Our calculations in Tables 10-12 show that - if oil and gasoline prices are even higher in 2015 - the blended mode case appears to have a reasonable chance of realizing net benefits for U.S. consumers, due to the lower costs estimated in this hypothetical example. For some European consumers who drive in a manner similar to the U.S. driving cycles simulated here, the blended mode PHEV does appear to be capable of generating net benefits in comparison to a petrol hybrid, at current petrol and residential electricity prices. However, both petrol hybrids and PHEVs must compete with the diesel, a case we have not evaluated in this paper. The hypothetical AER cases do not appear to be as likely to realize net savings to consumers, at the fuel and electricity prices used.

However, regulatory credits obtainable for nominal AER in California [32] and other states that adopt the California low emissions vehicle (LEV) standards may make it worthwhile to manufacturers to produce PHEVs with AER for those states, and cross subsidize those PHEVs, lowering retail prices. By doing so, the manufacturers may obtain credits that could allow avoidance of higher costs to meet the regulation by other means. This possibility obviously depends on costs of alternative means of obtaining credits. Further, as our comparison of Tables 4 and 5 indicate, the PHEV with CDE (AER) should have a larger technical market than the PHEVB with a similar $\mathrm{kWh}$ capability. Thus, there would be some merit in having any future federal credit system for probable petrol (petroleum) savings provide a greater per $\mathrm{kWh}$ incentive for a $\mathrm{PHEV}$ with CDE than for a PHEVB.

\section{IMPLICATIONS}

One of the fundamental questions that engineers are attempting to address when developing and interpreting the MWP or UF shown in Figure 1 is how much credit for eliminating petroleum use should an individual PHEV be given? For government officials and public interest groups seeking to reduce national oil use, the fear is that the PHEV could be like the FFV, in the sense that the latter has been given credits (limited in total, however) in the Corporate Average Fuel Economy regulations that assume that gasoline use of FFVs is reduced by $50 \%$. Yet very little alcohol fuel is actually used by the FFVs on-road. One can see, by inspection of Figure 1 that a PHEV of $\sim 48-56 \mathrm{~km}$ of AER might be granted a credit of $\sim 50 \%$ magnitude under the MWP or UF approach. However, arguments developed in this paper suggest problems in establishing PHEVs with this amount of AER, both because of battery volume (storage space considerations) and cost (power to achieve AER).

One point about the MWP and UF that is hopefully clear from this paper is that the underlying assumption is what would happen if PHEVs of a given range replaced all U.S. vehicles. Obviously, this is not possible for many years. Rather, what can be expected is attainment of a small share of the market in the first decade following introduction, perhaps on the order of $1^{-}$ $2 \%$ of the market, if oil prices remain at present levels. This has been the path for HEVs to date. Many have argued that HEVs do not provide net financial benefits. Nevertheless, like our blended mode case here, the net benefits are close to positive and enough consumers are excited about the technology to make it viable. The CAFE FFV credit does provide one useful reference point, the placement of a maximum total credit on the technology. There is no reason not to do the same thing for PHEVs, recognizing that they may attain relatively small market share in their first decade.

The question is what assumptions should be used to develop credits for the first wave of PHEVs? This paper argues that the $\mathrm{PHEV}$ is a complement to the $\mathrm{HEV}$, with a comparative advantage in driving at higher average speeds, to complement the lower average speed benefits of the HEV. Although we have compared the fuel savings benefits to HEV CS operation, the fact is that a significant portion of PHEVs sold should displace gasoline or diesel powertrains rather than HEV powertrains. For those cases the fuel savings benefits of PHEVs, from the perspective of saving oil for the nation, will be larger than we have estimated here.

Our analysis implies that it may be productive to think in terms of fuel saved per kWh of battery pack installed in vehicles, and compute total national oil savings, or corporate average fleet oil savings on the basis of total $\mathrm{kWh}$ of battery pack capacity sold in PHEVs, perhaps also tied to the number of cycles for which the pack is warranted. This is one option.

The second option is to provide a credit assuming that $\mathrm{kWh}$ will be used if a PHEV is purchased. The PHEV is very different from an FFV, making this assumption far more reasonable in the case of the PHEV. The FFV's incremental cost is low, but ethanol fuel costs more per kilometer of service provided, so the result is that no fuel is used. For the PHEV the opposite is true. The incremental cost of the vehicle is high, while the cost of fuel is low. Accordingly, the assumption that electricity will be used is quite reasonable.

Our paper indirectly addresses the question of how much fuel would be saved if the PHEV is sold to those basing their choice primarily on a financial basis. The argument is that PHEVs would be selected by persons who would drive considerably more kilometers per day on average than the CD range of the vehicle. There would be a weak tendency not to purchase a PHEV if the daily driving distance were much more than the CD range, due to estimated losses in CS mode. However, for a PHEV32, relatively few consumers would drive such distances, on average days. Although it may not be 
obvious, our best guess is that the implications of this paper are that PHEVs should be selectively purchased by persons likely to reduce fuel consumption by at least half in the case where the PHEV operates in AER; somewhat less if it operates in blended mode. We believe this finding is generic and not subject to CD range provided by any single PHEV model. In other words, in contrast to the implication of a rising credit with PHEV CD range in the MWP and UF approach, the implications of our analysis is that a constant credit, independent of CD range is appropriate. These implications certainly are subject to review and evaluation, given the dramatically different implications than found in current thinking.

Note that, if higher credits for PHEVs with AER than for those with CDB operation (holding $\mathrm{kWh}$ constant) were granted, an incentive to overcome the increased costs of AER would be provided. The implications discussed in this section may not hold for PHEVs with CD range considerably less than the average daily distance driven in the U.S., which is about $50 \mathrm{~km} /$ day. Our estimates also imply that PHEVs with from 16 to $32 \mathrm{~km}$ of AER, and $32 \mathrm{~km} \mathrm{CDB}$, could achieve considerably higher market penetration per $\mathrm{kWh}$ of battery pack investment (per unit of CD range provided) than more costly PHEVs with greater $\mathrm{CD}$ range. The implication is that such PHEVs would be a good way to initiate PHEV powertrain technology, making best use of dollars spent on batteries.

\section{ACKNOWLEDGMENTS}

The authors of this paper would like to gratefully acknowledge the sponsorship of Ed Wall, Program Manager and Tien Duong, Team Leader, Vehicle Technologies, Office of FreedomCar and Vehicle Technology, U.S, Department of Energy

The submitted manuscript has been created by UChicago Argonne, LLC, Operator of Argonne National Laboratory (“Argonne"). Argonne, a U.S. Department of Energy Office of Science laboratory, is operated under Contract No. DEAC02-06CH11357. . The U.S. Government retains for itself, and others acting on its behalf, a paid-up nonexclusive, irrevocable worldwide license in said article to reproduce, prepare derivative works, distribute copies to the public, and perform publicly and display publicly, by or on behalf of the Government.

\section{REFERENCES}

1. Graham, R., et al., Comparing the Benefits and Impacts of Hybrid Electric Vehicle Options, Final Report, Electric Power Research Institute, Palo Alto, Calif, ( July 2001).

2. U.S. Department of Transportation, 1995 Nationwide Personal Transportation Survey: Compact Disk and Codebook, U.S. Department of Transportation, Federal Highway Administration, Washington, DC, 1997.

\section{(C) 2008 WEV Journal, pp. $x-x$}

3. U.S. Department of Transportation, 2001 National Household Travel Survey: Compact Disk and User's Guide, U.S. Department of Transportation, Washington, DC, 2004.

4. U.S. Department of Energy, PHEVAmerica, Advanced Vehicle Testing Activity: Hymotion Plug-in Hybrid, Electric Transportation Applications. Idaho National Laboratory website: http://avt.inl.gov/phev.shtml 2007.

5. U.S. Department of Energy, PHEVAmerica, Advanced Vehicle Testing Activity: Energy CS Plug-in Hybrid, Electric Transportation Applications. Idaho National Laboratory website: http://avt.inl.gov/phev.shtml 2006.

6. Carlson, Richard, et al. Testing and Analysis of Three Plug-in Hybrid Electric Vehicles. SAE 2007-01-0283, SAE World Congress, Detroit, MI, April 2007.

7. Duoba, M. and R. Carlson, Test Procedures and Benchmarking: Blended-Type and EV-Capable Plug-in Hybrid Electric Vehicles, Advanced Lithium-Ion Batteries for Plug-In Hybrid-Electric Vehicles, Electric Vehicle Symposium 23, Anaheim CA Dec.2-5, 2007.

8. Anderman, M., HEV Batteries on the Eve of a Technology Change, Presentation at the Advanced Automotive Battery \& Ultracapacitor Conference, Long Beach, CA, May 16-18, 2007.

9. Gaines, L. and R. Cuenca, Costs of Lithium Ion Batteries for Vehicles, Argonne National Laboratory Report ANL/ESD-42, Argonne IL, May, 1999.

10. T. Miller, Requirement for Lithium Ion to Enter the Automotive Business, Presentation at the Advanced Automotive Battery \& Ultracapacitor Conference, Long Beach, CA, Ford Motor Company, May 16-18, 2007.

11. Sharer et al., Vehicle Simulation Results for Plug-in HEV Battery Requirements, Electric Vehicle Symposium 22, EVS-22. Moving to Sustainable Mobility, Yokohama Japan, Oct. 23-28, 2006.

12. Santini, D.J., and A.D. Vyas, Suggestions for a New Vehicle Choice Model Simulating Advanced Vehicle Introduction Decisions (AVID): Structure and Coefficients, Argonne National Laboratory Report ANL/ESD/05-1 Argonne, IL, Jan. 2005.

13. Brooke, L. Hot off the Grid, Automotive Engineering, April 2007, pp 52-56.

14. U.S. Department of Energy Office of FreedomCar and Vehicle Technologies, Summary Report - May 4-5 Discussion Meeting on Plug-in Hybrid Electric Vehicles, U.S. Department of Energy Web Site http://www1.eere.energy.gov/vehiclesandfuels/pdfs/prog ram/plug-in_summary_rpt.pdf, August 2006.

15. Kromer, M.A., and J. B. Heywood, Electric Powertrains: Opportunities and Challenges in the U.S. Light-Duty Vehicle Fleet, M.I.T. Laboratory for Energy and the Environment Publication No. LFEE 2007-03 RP. May 2007.

16. Duoba et al. Analysis of Power-Split HEV Control Strategies Using Data from Several Vehicles. SAE paper no. 2007-01-0291. International Society of Automotive Engineers, Warrendale, MI, 2007.

17. Alexander, M., M. Duvall, and S. Chhaya. An 
Assessment of Plug-in Hybrid Electric Vehicle Powertrain Architectures. Electric Vehicle Symposium 23, Anaheim CA Dec.2-5, 2007.

18. Howell, D., Electrical Energy Storage. Plug-in Hybrid Electric Vehicle Battery Research and Development Activities, Presented at the U.S. Department of Energy PHEV Stakeholder Workshop, Washington DC, June 13, 2007.

19. House, V.E., Status of Lithium Batteries Using Lithium Titanate Based Anode, ZEV Technology Symposium. California Air Resources Board. Sacramento CA Sept. 27, 2006.

20. Nelson, P. et al, Advanced Lithium-Ion Batteries for Plug-In Hybrid-Electric Vehicles Electric Vehicle Symposium 23, Anaheim CA Dec.2-5, 2007.

21. Nelson, P. personal communication, Oct. 15, 2007 22. California Air Resources Board, California Exhaust Emissions Standards and Test Procedures for 2005 and Subsequent Model Zero Emissions Vehicles, and 2001 and Subsequent Model Hybrid Electric Vehicles, in the Passenger Car, Light-Duty Truck and Medium-Duty Vehicle Classes, California Air Resources Board. Sacramento CA, Amended Dec. 19, 2003.

23. U.S. Environmental Protection Agency, Fuel Economy Labeling of Motor Vehicle: Revisions to Improve Calculation of Fuel Economy Estimates, Office of Transportation and Air Quality, Report EPA420-R-06017, 2006.

24. Gaines, L. et al., Sorting Through the Many Totalenergy-cycle Pathways Possible with Plug-in Hybrids. Electric Vehicle Symposium 23, Anaheim CA Dec.2-5, 2007.

25. Markel, T., Plug-in HEV Vehicle Design Options and Expectations, ZEV Technology Symposium. California Air Resources Board. Sacramento CA Sept. 27, 2006.

26. Leiby, P. and J. Rubin, The Alternative Fuel Transition: Results from the TAFV Model of Alternative Fuel Use in Light Duty Vehicles, 1996 to 2010, ORNL/TM2000/168 Oak Ridge National Laboratory, Oak Ridge, TN Sept. 17, 2000.

27. National Highway Traffic Safety Administration, Vehicle Survivability and Travel Mileage Schedules, U.S. Department of Transportation, National Center for Statistics and Analysis Report DOT HS 809 952, 2006. 28. Clement-Nyns, K., K. Van Reusel and J. Driesen. The Consumption of Electrical Energy of Plug-in Hybrid Electric Vehicles in Belgium. EET-2007 European EleDrive Conference, Brussels, Belgium. May 30-June 1, 2007.

29. Duong, T., Battery Requirements and Solutions for Plug-in Hybrids, Presentation at the Advanced Automotive Battery \& Ultracapacitor Conference, Long Beach, CA May 16-18, 2007.

30. FreedomCar and Vehicle Technologies Program, FY 2006 Progress Report for Energy Storage and Development. Office of Energy Efficiency and Renewable Energy, U.S. Department of Energy, Washington, DC. Jan 2007.

31. Ricardo Engineering and ASG Renaissance, Plug-
In Hybrid Electric Vehicle (PHEV) and Lifecycle Cost Methodology: Quantifying the Affordability Structure from Both the Supply and End-User Perspective Using Value Analysis, Presented at the California Air Resources Board ZEV Technology Symposium, Sept 2006.

32. State of California, The California Low-Emission Vehicle Regulations for Passenger Cars, Light-Duty Trucks and Medium-Duty Vehicles, including all or portions of Sections 1900, 1956.8, 1960.1, 1960.5, 1961, 1961.1, 1962, 1962.1, 1965, 1976, 1978, 2062, and 2101, title 13, California Code of Regulations, as of October 11, 2007

\section{AUTHORS}

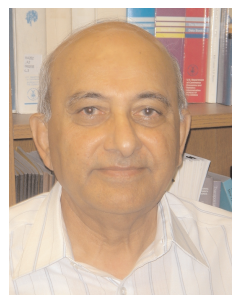

Mr. Vyas is a Transportation Systems Engineer at Argonne's Center for Transportation Research. He conducts research on transportation demand, market potentials of transportation technologies and materials, and environmental impacts of new technologies. During his 27 years at the Argonne National Laboratory, he has developed and exercised mathematical, simulation, and cost models for evaluation of technologies, materials, alternative fuels, policies, and regulations. Mr. Vyas has written or contributed to over 100 reports, journal articles, conference papers, and presentations.

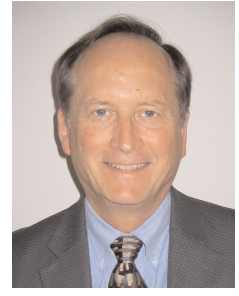

Dr. Danilo Santini is a Senior Economist and Section Leader of the Technology Analysis Section. He has worked at Argonne for over 33 years, mostly in assessments of energy and environmental technologies. His section developed models for evaluating costs and benefits of highway transportation technology, including emissions of criteria pollutants and greenhouse gases. Dan has written or contributed to over 150 articles, reports and conference papers. Since May of 2001, he has been the U.S. Department of Energy's technical representative to the International Energy Agency Implementing Agreement on Electric and Hybrid Vehicles. From 2003 to 2006 he was a member of the American Transportation Research Institute's Research Advisory Committee.

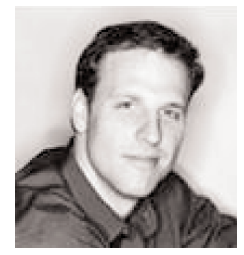

Michael Duoba, Mechanical Engineer, Argonne National Laboratory 9700 South Cass, Argonne, IL, USA ph: 630-252-6398 e-mail: mduoba@anl.gov

Since 1997, Mr. Duoba has been the lead engineer for ANL's Advanced Powertrain Research Facility. He is currently serving as the chair of SAE J1711 HEV test procedure re-issue task force, with primary focus on developing standard 
test procedures for PHEVs. Duoba has a Masters in Mechanical Engineering from University of WisconsinMadison.

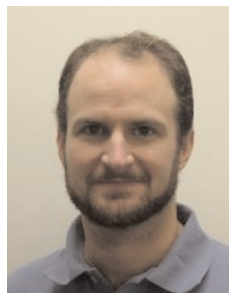

Mark Alexander is a project manager and analyst for the Electric Transportation program at the Electric Power Research Institute. He is primarily responsible for the development of hybrid electric vehicle simulations and control strategies for plug-in hybrid and fuel cell vehicles.

Mark also manages EPRI's field test demonstration data acquisition program, including hardware design and data analysis. Mark holds a BS in Mechanical Engineering and an MS in Electrical Engineering from the University of California, Davis. 